\title{
Characteristics of Temperature and Humidity Inversions and Low-Level Jets over Svalbard Fjords in Spring
}

\author{
Timo Vihma, ${ }^{1}$ Tiina Kilpeläinen,,3 Miina Manninen, ${ }^{2,4}$ Anna Sjöblom,, ${ }^{2,3}$ Erko Jakobson, ${ }^{5,6}$ \\ Timo Palo, ${ }^{7}$ Jaak Jaagus, ${ }^{7}$ and Marion Maturilli ${ }^{8}$
}

${ }^{1}$ Meteorological Research, Finnish Meteorological Institute, 00101 Helsinki, Finland

${ }^{2}$ Department of Arctic Geophysics, The University Centre in Svalbard, 9171 Longyearbyen, Norway

${ }^{3}$ Geophysical Institute, University of Bergen, 5020 Bergen, Norway

${ }^{4}$ Department of Physics, University of Helsinki, 00014 Helsinki, Finland

${ }^{5}$ Department of Physics, University of Tartu, 50090 Tartu, Estonia

${ }^{6}$ Tartu Observatory, 61602 Tõravere, Estonia

${ }^{7}$ Department of Geography, University of Tartu, 50090 Tartu, Estonia

${ }^{8}$ Research Unit Potsdam, Alfred Wegener Institute for Polar and Marine Research, D-14473 Potsdam, Germany

Correspondence should be addressed to Timo Vihma, timo.vihma@fmi.fi

Received 9 June 2011; Revised 7 December 2011; Accepted 13 December 2011

Academic Editor: Igor N. Esau

Copyright ( $) 2011$ Timo Vihma et al. This is an open access article distributed under the Creative Commons Attribution License, which permits unrestricted use, distribution, and reproduction in any medium, provided the original work is properly cited.

\begin{abstract}
Air temperature and specific humidity inversions and low-level jets were studied over two Svalbard fjords, Isfjorden and Kongsfjorden, applying three tethersonde systems. Tethersonde operation practices notably affected observations on inversion and jet properties. The inversion strength and depth were strongly affected by weather conditions at the $850 \mathrm{hPa}$ level. Strong inversions were deep with a highly elevated base, and the strongest ones occurred in warm air mass. Unexpectedly, downward longwave radiation measured at the sounding site did not correlate with the inversion properties. Temperature inversions had lower base and top heights than humidity inversions, the former due to surface cooling and the latter due to adiabatic cooling with height. Most low-level jets were related to katabatic winds. Over the ice-covered Kongsfjorden, jets were lifted above a cold-air pool on the fjord; the jet core was located highest when the snow surface was coldest. At the ice-free Isfjorden, jets were located lower.
\end{abstract}

\section{Introduction}

Temperature inversions are common in the Arctic, especially in winter [1-3]. They can be generated by various mechanisms, including (a) surface cooling due to a negative radiation budget, the effects of which are transmitted to near-surface air via a downward sensible heat flux [4], (b) direct radiative cooling of the air $[5,6]$, (c) warm-air advection over a cold surface $[7,8]$, and (d) subsidence $[1,9]$. Also specific humidity inversions (hereafter humidity inversions) are common in the Arctic [10] and they often coincide with temperature inversions [11]. Despite the importance of humidity inversions for the Arctic stratus [12], the mechanisms generating humidity inversions have received much less attention than those generating temperature inversions. Condensation, gravitational fallout of the condensate, deposition of hoar frost at the surface, turbulent transport of moisture, and subsidence are processes in vertical dimension that contri bute to the generation of humidity inversions [13]. In addition, horizontal advection of moist air masses from lower latitudes is an essential large-scale process; the advection peaks above the atmospheric boundary layer $(\mathrm{ABL})$ but there is still significant uncertainty on its vertical distribution [14].

A low-level wind maximum called a low-level jet (LLJ) is a typical feature in the wind profile in the Arctic, in particular in the presence of temperature inversions, when the LLJ is often located at the top of the temperature inversion [15]. LLJs can be generated by a variety of mechanisms, including (a) inertial oscillations due to temporal $[16,17]$ and spatial [18] variations in the surface friction, (b) baroclinicity [19], (c) directional shear of other origin [20], (d) ice breeze 
(a sea-breeze-type mesoscale circulation; [21]), (e) katabatic winds [22], and (f) barrier winds [23].

Major challenges still remain in understanding temperature and humidity inversions, LLJs, and other features in the stable boundary layer (SBL). The Arctic SBL is long-living with a strong but quantitatively poorly known interaction of gravity waves and turbulence [24]. Under very stable stratification, the shear related to a low-level jet often provides a source of turbulence more important than the surface friction, resulting in an upside-down structure of the SBL [25]. Further, shallow convection over leads and polynyas complicates $A B L$ processes in the sea ice zone $[26,27]$. Hence, numerical weather prediction (NWP) and climate models usually have their largest errors in the SBL [28-31], which calls for more analyses on the temperature and humidity profiles and low-level jets in the Arctic atmosphere.

Arctic fjords are usually surrounded by a complex orography of mountains, valleys, and glaciers, which complicates the dynamics of the air flow [32]. In Svalbard, some fjords are completely covered by sea ice in winter and spring whereas others are partly ice-free; in the latter the surface temperature varies largely in space. The low-level wind field is strongly influenced by the local orography [33]. Due to the combined effects of the complex orography and thermal heterogeneity of the fjord surface, the dynamic and thermodynamic processes affecting the state of the ABL are complex. Several studies have addressed boundary-layer and mesoscale processes in the Svalbard region, including observations on surface-layer turbulence $[34,35]$ and ABL structure $[36,37]$ and modelling studies with validation against observations from satellite [38], research aircraft $[8,39]$, unmanned aircraft [40], automatic weather stations [41], and rawinsonde soundings [42]. What has been lacking so far is a thorough observational analysis on temperature and humidity inversions and low-level jets, based on a data set more extensive than those in previous case studies $[8,39]$.

Our study is motivated by two aspects. First, better understanding on the ABL structure over fjords is needed to improve NWP and climate models and to improve the skill of duty forecasters to predict near-surface weather in conditions of complex orography, where present-day operational models are not particularly reliable [42]. Considering climate modelling, the vertical profiles of wind, temperature, and humidity closely interact with the turbulent surface fluxes, which further control the deep water formation in fjords with potentially far-reaching effects on the climate system [43]. Second, several studies on the structure of the ABL in polar regions have been based on tethersonde soundings (e.g., $[17,36,37])$, but a detailed investigation on the effects of the sounding strategy (above all, vertical resolution and maximum height) on the observations of inversions and LLJs is still lacking. To respond to these needs, we analyse (1) the effects of synoptic-scale flow and surface conditions on the temperature and humidity inversions, (2) the effects of synoptic-scale flow, near-surface temperatures, and orography on LLJs, and (3) the sensitivity of the results to the method of taking tethersonde soundings. We study the ABL over Isfjorden and Kongsfjorden on the basis of data from three different tethersonde systems operated in spring 2009. We have
TABLE 1: Vaisala DigiCORA TT12 tethersonde sensors with accuracies and resolutions.

\begin{tabular}{llcc}
\hline Variable & Sensor & $\begin{array}{c}\text { Absolute } \\
\text { accuracy* }\end{array}$ & Resolution \\
\hline Air temperature & $\begin{array}{l}\text { Capacitive wire } \\
\text { F-Thermocap }\end{array}$ & $0.5^{\circ} \mathrm{C}$ & $0.1^{\circ} \mathrm{C}$ \\
Relative humidity & $\begin{array}{l}\text { Thin-film capacitor } \\
\text { Three-cup } \\
\text { anemometer }\end{array}$ & $5 \%$ & $0.1 \%$ \\
Wind speed & $\begin{array}{l}\text { Digital compass } \\
\text { Wind direction }\end{array}$ & $\begin{array}{c}\text { See the } \\
\text { text }\end{array}$ & $0.1 \mathrm{~m} \mathrm{~s}^{-1}$ \\
$\begin{array}{l}\text { Atmospheric } \\
\text { pressure }\end{array}$ & $\begin{array}{l}\text { BAROCAP silicon } \\
\text { sensor }\end{array}$ & $1.5 \mathrm{hPa}$ & $0.1 \mathrm{hPa}$ \\
\hline
\end{tabular}

* The accuracy of vertical differences is better than the absolute accuracy, because in the UNIS and UT soundings the same sensors were used for the whole profile and in the AWI tethersonde the sensors were intercalibrated. We assume that the accuracy of vertical differences in air temperature and relative humidity is close to the sensor resolution.

already applied these data to verify high-resolution numerical model simulations [44], but without addressing the above-mentioned aspects 1-3.

\section{Observations}

2.1. Tethersonde System. Three basically similar tethersonde systems (DigiCORA TT12, Vaisala) were operated at coastal areas of Svalbard in March-April 2009. The measurements near Longyearbyen on the southern coast of Isfjorden were made by the University Centre in Svalbard (UNIS) and the measurements at $\mathrm{Ny}$ Ålesund on the southern coast of Kongsfjorden by the University of Tartu (UT) and the Alfred Wegener Institute for Polar and Marine Research (AWI) (Figure 1). The UNIS tethersonde system consisted of one tethersonde and the UT system of three tethersondes at approximately $15 \mathrm{~m}$ intervals in the vertical, attached to a tethered balloon (Figure 2). The UNIS and UT balloons were ascended and descended with a constant speed of approximately $1 \mathrm{~m} \mathrm{~s}^{-1}$ to gain vertical profiles of temperature, humidity, pressure, wind speed, and wind direction. The AWI system (Figure 2) consisted of six tethersondes, which were kept at constant altitudes, from $100 \mathrm{~m}$ to $600 \mathrm{~m}$ at $100 \mathrm{~m}$ intervals in the vertical, to record time series. The sampling interval of the tethersondes altered from 1 to 5 seconds. The tethersonde systems were only operated in nonprecipitating conditions (except of very light snow fall) with wind speeds less than $10 \mathrm{~m} \mathrm{~s}^{-1}$. The tethered balloons were neither ascended into thick clouds nor operated in temperatures lower than approximately $-25^{\circ} \mathrm{C}$. Technical information on the tethersonde sensors is given in Table 1.

2.2. Measurements at Isfjorden. Isfjorden, which covers an area of $3084 \mathrm{~km}^{2}$, is situated on the west coast of Spitsbergen, the largest island of the archipelago of Svalbard. The fjord is orientated in a southwest to northeast direction and has a $10 \mathrm{~km}$ wide mouth to the open ocean. The measurement site $\left(78^{\circ} 15^{\prime} \mathrm{N}, 15^{\circ} 24^{\prime} \mathrm{E}\right)$ was located on the southern coast of 


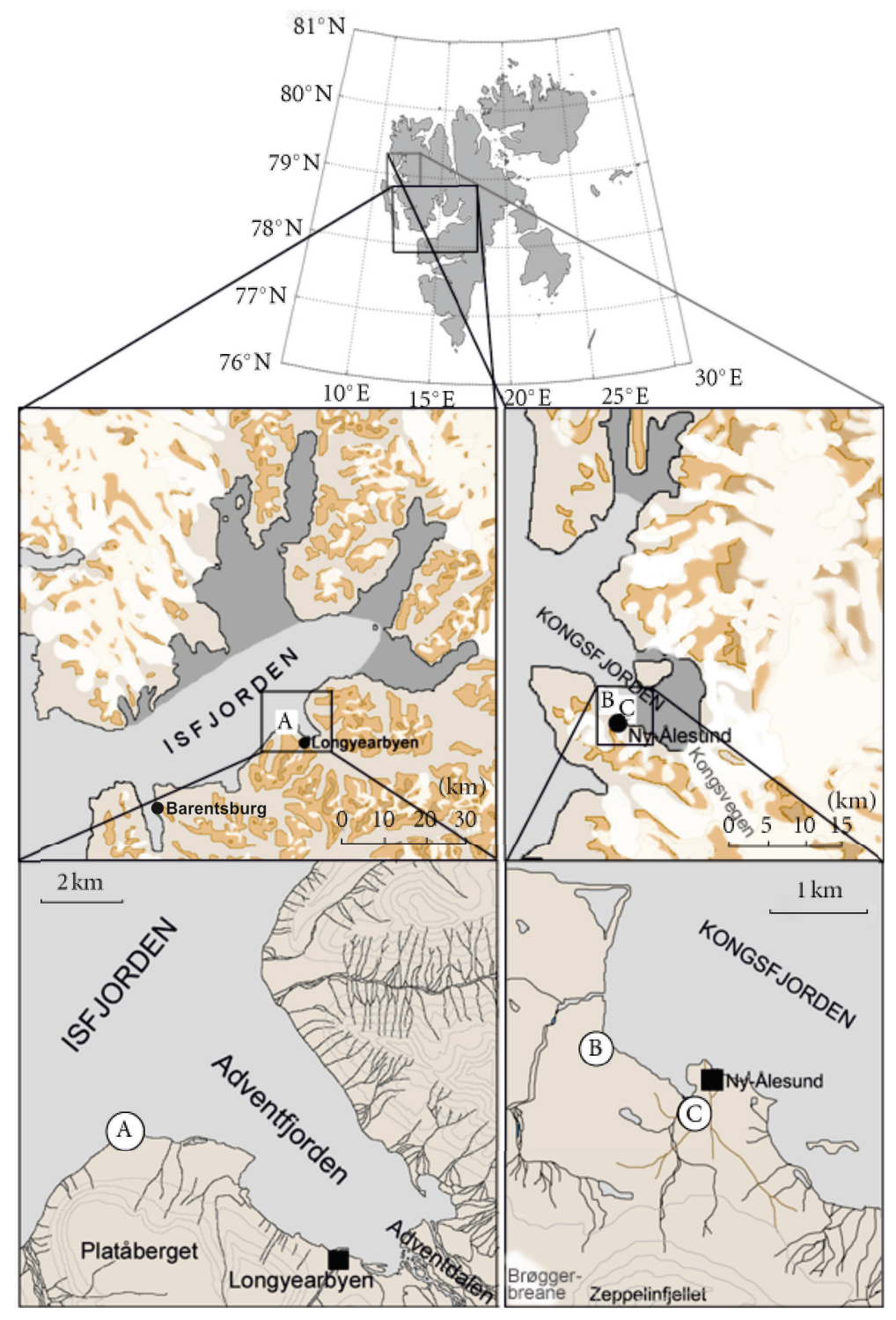

FIgURE 1: The locations of measurement site of UNIS (A) in Isfjorden, and UT (B) and AWI (C) in Kongsfjorden. In the middle panel, the dark gray shows the areas fully covered with land-fast sea ice and the light gray shows the areas with sea ice concentration varying between 0.2 and 0.9. In the lowest panel, the terrain height is shown with $100 \mathrm{~m}$ isolines.

Isfjorden, approximately $30 \mathrm{~m}$ from the shoreline, and had an undisturbed over-fjord fetch of approximately $25-40 \mathrm{~km}$ in a $175^{\circ}$ wide sector from southwest clockwise to northeast (Figure 1). The local orography around the site is very complex, consisting of mountains rising to heights of 400 $1100 \mathrm{~m}$, valleys, and glaciers.

At Isfjorden, the tethersonde campaign started on 29 March 2009 (day length $14 \mathrm{~h} 51 \mathrm{~min}$ ), and ended on 5 April 2009 (day length 16 h $51 \mathrm{~min}$ ). Altogether 27 soundings were made. Because the measurement site was in the vicinity of the Svalbard Airport, the balloon could only be operated when the airport was closed. The operating hours were often restricted to early mornings and afternoons (Figure 3 ). The balloon was always lifted as high as the cloud conditions, wind speed, and the buoyancy of the small $\left(2.5 \mathrm{~m}^{3}\right)$ balloon allowed. The maximum heights of the soundings varied from 230 to $890 \mathrm{~m}$.

Tower measurements were made next to the UNIS tethersonde sounding site (some $20 \mathrm{~m}$ apart). In 2008, a $30 \mathrm{~m}$ tower was equipped with meteorological sensors at several levels [34]; here we applied the measurements of air temperature and relative humidity (HMP45C, Vaisala) at the height of $10 \mathrm{~m}$, wind speed, and wind direction (A100LK and W200P, Vector instruments) at the heights of 10,15 , and $25 \mathrm{~m}$, as well as the surface pressure (CS100, Campbell Scientific). In addition, a net radiometer (CNR1, Kipp \& Zonen) was deployed to measure the downward and upward shortwave and longwave radiative fluxes, and a sonic anemometer (CSAT3, Campbell Scientific) at the height of $2.7 \mathrm{~m}$ was applied to measure turbulent fluxes of sensible heat and momentum. 


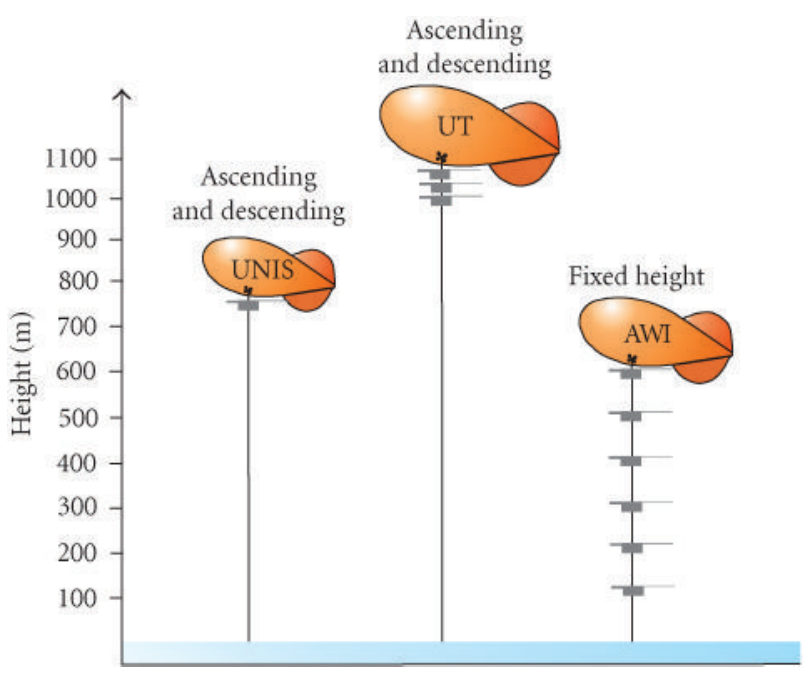

FIGURE 2: Schematic figure on the tethersonde sounding systems of the University Centre in Svalbard (UNIS), University of Tartu (UT), and Alfred Wegener Institute (AWI). The size of balloons is not in the scale of the vertical axis.

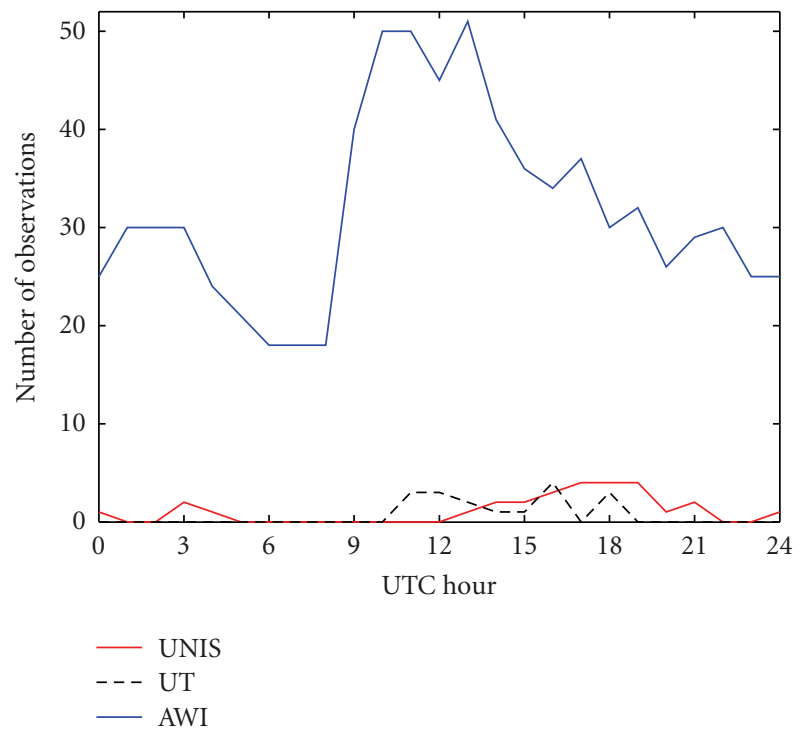

FIGURE 3: Diurnal distribution of tethersonde soundings.

In addition, the prevailing cloud and sea ice conditions were observed visually. The sea ice conditions were also analysed based on the sea ice charts produced by the Norwegian Meteorological Institute. In front of the measuring site, Isfjorden remained mostly free of ice, although there was occasionally pancake ice forming over night. The inner parts of the fjord branches were covered with land-fast ice (Figure 1).

2.3. Measurements at Kongsfjorden. Kongsfjorden is situated on the west coast of Spitsbergen and covers an area of approximately $220 \mathrm{~km}^{2}$. The fjord is orientated from northwest to southeast and has a $10 \mathrm{~km}$ wide mouth to the open ocean. The measurement sites of UT $\left(78^{\circ} 56^{\prime} \mathrm{N}, 11^{\circ} 51^{\prime} \mathrm{E}\right)$ and AWI $\left(78^{\circ} 55^{\prime} \mathrm{N}, 11^{\circ} 55^{\prime} \mathrm{E}\right)$ were located on the southern coast of
Kongsfjorden, $1.4 \mathrm{~km}$ apart from each other (Figure 1). At the measurement sites, the fjord is approximately $4-9 \mathrm{~km}$ wide in a $140-160^{\circ}$ wide sector. The local orography around the sites is very complex.

The tethersonde measurements of UT were made between 21 March (day length $12 \mathrm{~h} 51 \mathrm{~min}$ ) and 2 April 2009 (day length $16 \mathrm{~h} 16 \mathrm{~min}$ ); altogether 17 soundings were made. Depending on the cloud conditions, wind speed, and the buoyancy of the $7 \mathrm{~m}^{3}$ balloon, the maximum height of the soundings varied from 600 to $1500 \mathrm{~m}$ with an average of $1200 \mathrm{~m}$. The measurements of AWI were made between 12 March (day length $10 \mathrm{~h} 24 \mathrm{~min}$ ) and 5 April 2009 (day length $17 \mathrm{~h} 13 \mathrm{~min}$ ). The tethered balloon was launched whenever the weather conditions were appropriate, and kept at a constant altitude as long as the weather conditions and battery capacity allowed. During the campaign, 13 individual time series, 5 to $16 \mathrm{~h}$ each, were collected. The AWI tethersonde data covered all hours of the day whereas the UT soundings were only made between 10 and 19 UTC (Figure 3). Moreover, AWI carries out regular rawinsonde soundings at $\mathrm{Ny}$ Ålesund daily at 11 UTC, with the launching site next to the AWI tethersonde site. We also applied these data from the period of our campaign (14 rawinsonde soundings).

The near-surface temperature, relative humidity, and wind were measured at a $10 \mathrm{~m}$ weather mast of AWI, located approximately $300 \mathrm{~m}$ from the AWI sounding site. A $10 \mathrm{~m}$ weather mast of UT, equipped with wind, temperature, and humidity sensors (Aanderaa Co.) was situated at the coast, approximately $500 \mathrm{~m}$ from the AWI sounding site and $1 \mathrm{~km}$ from the UT sounding site. At this location, the downward and upward longwave radiation were measured by a pair of Eppley PIR pyrgeometers, and the downward and upward shortwave radiation by a pair of Eppley PSP pyranometers, and a sonic anemometer (Metek USA-1) was applied to measure the sensible heat flux. The cloud conditions were observed visually. The sea ice cover was estimated based on the sea ice charts produced by the Norwegian Meteorological Institute. The inner part of the fjord was covered with land-fast ice and the area towards the fjord mouth partly with drifting ice (Figure 1). Next to the measurement sites, a compact field of drifting ice prevailed.

\section{Data and Analysis Methods}

Only the ascent profiles of temperature, humidity, and wind direction were used in the analyses of the tethersonde data. However, to smoothen out the overestimation of wind speed during the descent and underestimation during the ascent, the values from both wind profiles were averaged. The profile data of UNIS were averaged over every $5 \mathrm{~m}$ to keep as good a resolution as possible. The data of UT was averaged over the three tethersondes. Due to the limited accuracy of the height measurements of each individual tethersonde, a $10 \mathrm{~m}$ averaging interval was used for the UT profiles. The nearsurface air temperature and humidity were taken from the lowest measurement altitude of $5 \mathrm{~m}$, and the wind speed and wind direction from the height of $10 \mathrm{~m}$. The tethersonde time series of AWI were averaged over $10 \mathrm{~min}$ at each level, which 
gave 770 vertical profiles based on the six tethersondes. The weather mast measurements and near-surface measurements of radiative and turbulent fluxes were averaged over $30 \mathrm{~min}$.

Wind direction measurements made with the tethersonde systems suffered from a systematic compass malfunction due to extreme sensitivity to sensor tilt in the vicinity of the magnetic pole. The differences between the tethersonde ascent profile and weather mast wind direction sensor readings were mostly within $30^{\circ}$. We concluded that the tethersonde wind directions were not accurate enough to study the turning of the wind in the $\mathrm{ABL}$, but the data still made it possible to detect from which of the nearby glaciers, mountains, or fjord branches the air mass was advected.

The operational analyses of the European Centre for Medium-Range Weather Forecasts (ECMWF), with $25 \mathrm{~km}$ horizontal resolution, were applied to get information on the geopotential height, wind speed, wind direction, temperature, temperature advection, relative humidity, and specific humidity at the $850 \mathrm{hPa}$ pressure level, above the local mountains. The air masses were classified as marine or Arctic according to the wind direction at the $850 \mathrm{hPa}$ level. Due to the tongue of the open ocean west of Svalbard and sea ice east and even southeast of Svalbard, the marine sector was defined as $200-290^{\circ}$, while the other wind directions represented the Arctic sector.

The terminology used to define a temperature inversion follows Andreas et al. [17]. The height of the inversion base $z_{T b}$ and the temperature of the inversion base $T_{b}$ were taken from the level immediately below the temperature inversion (Figure 4). The top of the temperature inversion is the subsequent level where the temperature starts to decrease. The height and temperature of this level were taken as the height of the inversion top $z_{T t}$ and the temperature of the inversion top $T_{t}$. Hence, temperature inversion strength TIS $=T_{t}-$ $T_{b}$, and temperature inversion depth TID $=z_{T t}-z_{T b}$. To ensure that no artificial inversions are generated due to measurement inaccuracy, cases where the temperature change through the inversion was $0.3^{\circ} \mathrm{C}$ or less were ignored. Thin negative lapse layers that occasionally occurred within the inversion layers were also ignored and considered to be within the inversion layer when they were less than $10 \mathrm{~m}$ thick and the temperature change within them was less than $0.3^{\circ} \mathrm{C}$. A specific humidity inversion terminology, such as the specific humidity at the inversion base $\left(q_{b}\right.$ at $\left.z_{q b}\right)$ and at the inversion top $\left(q_{t}\right.$ at $\left.z_{q t}\right)$ was determined analogously to temperature inversion (Figure 4). Accordingly, humidity inversion strength QIS $=q_{t}-q_{b}$, and humidity inversion depth QID $=z_{q t}-z_{q b}$. Layers with a humidity increase larger than $0.02 \mathrm{~g} \mathrm{~kg}^{-1}$ were considered as humidity inversion layers. Thin (less than $10 \mathrm{~m}$ ) layers of humidity decrease within the inversion layer were ignored.

A low-level jet was defined following Stull [15] as the level where there is a local wind speed maximum with wind speeds at least $2 \mathrm{~m} \mathrm{~s}^{-1}$ higher than wind speeds above it. As LLJs related to katabatic winds in Isfjorden often occur very close to the surface, the wind maxima often occurred at the lowest observation level of $10 \mathrm{~m}$. The level of maximum wind speed was defined as the jet core height $z_{j}$, with the jet core wind speed $U_{j} ; z_{a}$ is the height of the subsequent wind minimum,
TABLE 2: Comparison of simultaneous soundings by AWI and UT. $\mathrm{UT}_{600}$ refers to the inversion statistics based solely on the lowermost $600 \mathrm{~m}$ of the UT data. $N$ denotes the number of simultaneous observations for each variable. See Section 3 for definition of variables.

\begin{tabular}{lccc}
\hline Variable/N & AWI & $\mathrm{UT}$ & $\mathrm{UT}_{600}$ \\
\hline $\mathrm{TID} / 5$ & $193 \mathrm{~m}$ & $106 \mathrm{~m}$ & $109 \mathrm{~m}$ \\
$\mathrm{TIS} / 5$ & $3.9^{\circ} \mathrm{C}$ & $4.5^{\circ} \mathrm{C}$ & $4.1^{\circ} \mathrm{C}$ \\
$T_{b} / 5$ & $-20.0^{\circ} \mathrm{C}$ & $-19.5^{\circ} \mathrm{C}$ & $19.5^{\circ} \mathrm{C}$ \\
$T_{t} / 5$ & $-16.1^{\circ} \mathrm{C}$ & $-14.9^{\circ} \mathrm{C}$ & $-15.4^{\circ} \mathrm{C}$ \\
$\mathrm{QID} / 8$ & $203 \mathrm{~m}$ & $124 \mathrm{~m}$ & $59 \mathrm{~m}$ \\
QIS/8 & $0.07 \mathrm{~g} \mathrm{~kg}^{-1}$ & $0.18 \mathrm{~g} \mathrm{~kg}^{-1}$ & $0.11 \mathrm{~g} \mathrm{~kg}^{-1}$ \\
$Q_{b} / 8$ & $0.61 \mathrm{~g} \mathrm{~kg}^{-1}$ & $0.52 \mathrm{~g} \mathrm{~kg}^{-1}$ & $0.52 \mathrm{~g} \mathrm{~kg}^{-1}$ \\
$Q_{t} / 8$ & $0.68 \mathrm{~g} \mathrm{~kg}^{-1}$ & $0.70 \mathrm{~g} \mathrm{~kg}^{-1}$ & $0.62 \mathrm{~g} \mathrm{~kg}^{-1}$ \\
$z_{j} / 3$ & $208 \mathrm{~m}$ & $213 \mathrm{~m}^{-1}$ & $213 \mathrm{~m}^{-1}$ \\
$U_{j}-U_{a} / 3$ & $2.9 \mathrm{~m} \mathrm{~s}^{-1}$ & $3.9 \mathrm{~m} \mathrm{~s}^{-1}$ & $3.7 \mathrm{~m} \mathrm{~s}^{-1}$ \\
$U_{j} / 3$ & $5.2 \mathrm{~m} \mathrm{~s}^{-1}$ & $6.2 \mathrm{~m} \mathrm{~s}^{-1}$ & $6.2 \mathrm{~m} \mathrm{~s}^{-1}$ \\
\hline
\end{tabular}

and $U_{a}$ the corresponding wind speed (Figure 4). The LLJ depth was defined as $z_{a}-z_{j}$.

\section{Temperature and Humidity Inversions}

Inversions were observed during variable synoptic situations. Over Kongsfjorden, the $850 \mathrm{hPa}$ level wind speed ranged from 0 to $20 \mathrm{~m} \mathrm{~s}^{-1}$, the air temperature from -28 to $-12^{\circ} \mathrm{C}$, and the temperature advection from -2.9 to $2.6^{\circ} \mathrm{Ch}^{-1}$. Most common were moderate northerly winds (mean speed $7.3 \mathrm{~m} \mathrm{~s}^{-1}$ ) with a weak cold-air advection (mean $-0.3^{\circ} \mathrm{Ch}^{-1}$ ). Over Isfjorden, the $850 \mathrm{hPa}$ level wind speed varied from 3 to $10 \mathrm{~m} \mathrm{~s}^{-1}$, the air temperature from -20 to $-11^{\circ} \mathrm{C}$, and the temperature advection from -1.2 to $0.8^{\circ} \mathrm{Ch}^{-1}$.

4.1. Effects of the Sounding Practice. To quantify the methodological effects on observed temperature and humidity inversions, we compared the simultaneous soundings of AWI and UT. To distinguish between the effects of vertical resolution ( $10 \mathrm{~m}$ for UT (see Section 3), $100 \mathrm{~m}$ for AWI) and maximum sounding altitude (600-1500 m for UT, $600 \mathrm{~m}$ for AWI) in generating differences in the observed inversion properties, we also calculated the inversion statistics separately for a subset of the UT data only including the lowermost $600 \mathrm{~m}$ of the profiles (data from upper levels were ignored). The differences between this data subset (hereafter $\mathrm{UT}_{600}$ data) and simultaneous AWI soundings are solely due to vertical resolution.

The largest relative differences between the AWI and the original UT data sets, of the order of $100 \%$, were found in TID, QIS, and QID, with thicker inversions in the AWI data but stronger inversions in the UT data (Table 2). The differences in TID were almost entirely due to the coarse vertical resolution of the AWI data set, where many elevated inversions were sampled as surface based (UT and $\mathrm{UT}_{600}$ data gave practically same mean values, demonstrating an insignificant effect of maximum altitude). On the contrary, both 


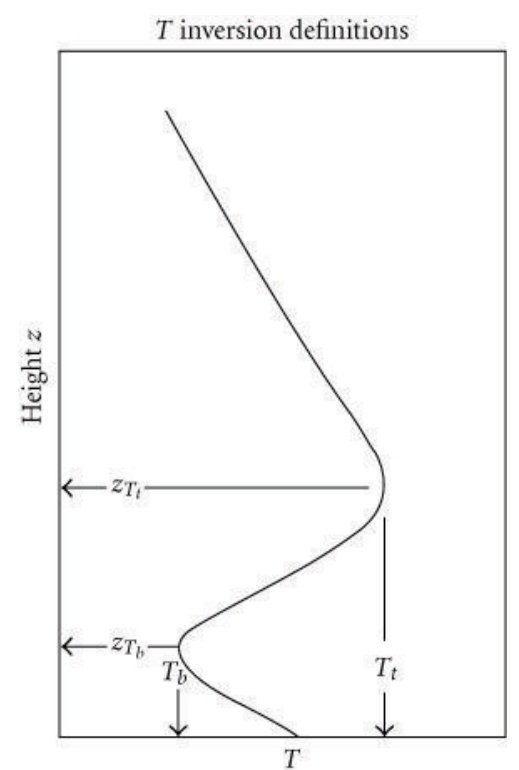

(a)

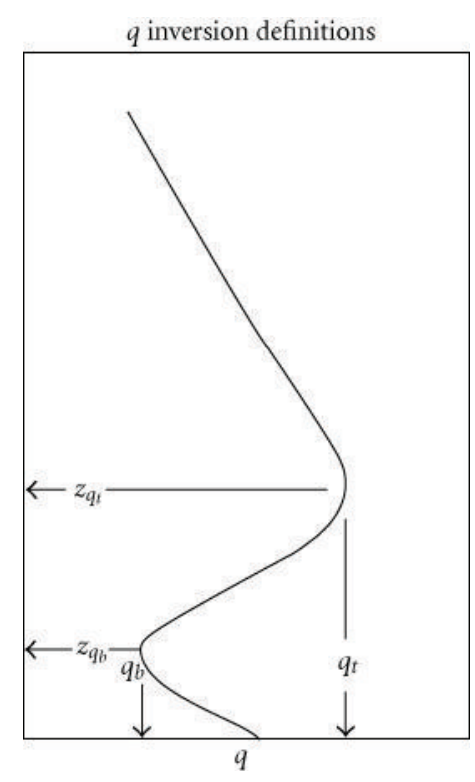

(b)

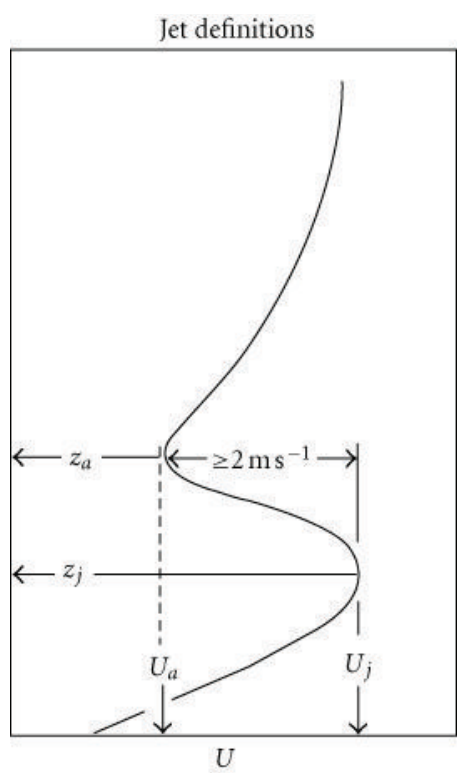

(c)

FIGURE 4: (a) Parameters of a temperature $T$ inversion: $z_{T b}$ is the height of the temperature inversion base, $z_{T t}$ the temperature inversion top height, $T_{b}$ the temperature at the inversion base, and $T_{t}$ the temperature at the inversion top; (b) Parameters of a humidity inversion: $z_{q b}$ is the height of the humidity inversion base, $z_{q t}$ the humidity inversion top height, $q_{b}$ the specific humidity at the inversion base, and $q_{t}$ the specific humidity at the inversion top. (c) Parameters of a low-level jet. $z_{j}$ is the height of the jet core and $U_{j}$ the wind speed of the jet core. $z_{a}$ is the height of the wind minimum above the jet core and $U_{a}$ the wind speed there. Modified from Andreas et al. [17].

the vertical resolution and maximum altitude were essential in generating differences in QID and QIS: the three data sets yielded dramatically different mean values (Table 2 ). For QID the AWI data yielded the largest values, as many elevated inversions were sampled as surface based and separate inversion layers were often counted as one. For QIS, however, the largest values were found in the UT data; the AWI data missed both the maximum humidities that occurred above $600 \mathrm{~m}$ and the minimum humidities that were not detected due to the coarse vertical resolution. TIS was less affected by the sounding practice, because temperature inversions on average reached lower heights than humidity inversions. UT data also allowed better detection of the fine structure of the wind profiles, resulting in stronger LLJs and core wind speeds (Table 2). As the LLJs occurred in the lowermost $600 \mathrm{~m}$, the differences in core winds were solely due to vertical resolution, but the jet strength was also affected by the wind minimum, which was sometimes located above $600 \mathrm{~m}$.

The data sets included four cases with simultaneous soundings by both tethersondes and the AWI rawinsonde system. In two of these cases the rawinsonde data missed the strong temperature inversions that occurred in the lowermost $100 \mathrm{~m}$ layer. Using UT tethersonde data as reference, the warm bias in the rawinsonde data was up to $4.5^{\circ} \mathrm{C}$.

4.2. Basic Inversion Properties. Statistics of temperature and humidity inversions are summarized in Table 3. Looking at the mean values of all three data sets (UNIS, UT, and AWI), the temperature inversions had a lower base height than the humidity inversions, but the humidity inversions were thicker and had a higher top. The reason for the tem- perature inversions not reaching as high altitudes as humidity inversions is the adiabatic cooling; no comparable mechanism affects the specific humidity in unsaturated air (the tethersondes did not enter into clouds). The reason for the lower base height for temperature inversions is that the snow surface acted as a heat sink: the observed sensible heat flux was from air to snow for $90 \%$ of the time in Isfjorden and $93 \%$ of the time in Kongsfjorden. Surface-based temperature inversions were therefore common and, in the case of an elevated inversion, forced convection was seldom strong enough to generate a thick mixed layer below the elevated inversion. On the contrary, the snow surface was seldom a sink for air humidity. The observations indicated that the surfacespecific humidity (calculated from the surface temperature based on the longwave radiation data) exceeded the air-specific humidity (weather mast data from 2-10 m height) for $79 \%$ and $63 \%$ of the time in Isfjorden and Kongsfjorden, respectively. Such conditions did not favour surface-based humidity inversions.

The mean profiles for air masses of marine and Arctic origin are shown in Figure 5. Considering the temperature profiles, UNIS soundings showed that the marine air masses were much warmer than the Arctic ones, but the temperature inversions were stronger in the marine than Arctic air mass (mean TIS 2.3 and $1.6^{\circ} \mathrm{C}$, resp.). This was partly due to the warmer air at higher altitudes and partly due to the surface cooling (down to $-9^{\circ} \mathrm{C}$ on average) during the flow of marine air masses over western parts of Svalbard archipelago before reaching the sounding site. At Kongsfjorden, the marine air masses were typically $2-3^{\circ} \mathrm{C}$ warmer than the Arctic ones. Contrary to Isfjorden, the both Kongsfjorden data 
TABLE 3: Statistics of temperature and humidity inversions. See the text for definition of the symbols.

\begin{tabular}{lccccc}
\hline \multirow{2}{*}{ Data set* } & \multicolumn{3}{c}{ Temperature inversions } & \multicolumn{2}{c}{ Humidity inversions } \\
& Variable & Mean & Std & Variable & Mean \\
\hline UNIS & $z_{T b}(\mathrm{~m})$ & 107 & 192 & $z_{q b}(\mathrm{~m})$ & 210 \\
UNIS & $z_{T t}-z_{T b}(\mathrm{~m})$ & 54 & 39 & $z_{q t}-z_{q b}(\mathrm{~m})$ & 62 \\
UNIS & $T_{b}\left({ }^{\circ} \mathrm{C}\right)$ & -15.9 & 5.0 & $q_{b}\left(\mathrm{~g} \mathrm{~kg}^{-1}\right)$ & 0.77 \\
UNIS & $T_{t}-T_{b}\left({ }^{\circ} \mathrm{C}\right)$ & 1.4 & 1.0 & $q_{t}-q_{b}\left(\mathrm{~g} \mathrm{~kg}^{-1}\right)$ & 0.77 \\
UT & $z_{T b}(\mathrm{~m})$ & 423 & 374 & $z_{q b}(\mathrm{~m})$ & 472 \\
UT & $z_{T t}-z_{T b}(\mathrm{~m})$ & 92 & 59 & $z_{q t}-z_{q b}(\mathrm{~m})$ & 103 \\
UT & $T_{b}\left({ }^{\circ} \mathrm{C}\right)$ & -18.2 & 4.5 & $q_{b}(\mathrm{~g} \mathrm{~kg})$ & 334 \\
UT & $T_{t}-T_{b}\left({ }^{\circ} \mathrm{C}\right)$ & 1.7 & 1.8 & $q_{t}-q_{b}\left(\mathrm{~g} \mathrm{~kg}^{-1}\right)$ & 0.72 \\
AWI & $z_{T b}(\mathrm{~m})$ & 85 & 146 & $z_{q b}(\mathrm{~m})$ & 0.11 \\
AWI & $z_{T t}-z_{T b}(\mathrm{~m})$ & 184 & 120 & $z_{q t}-z_{q b}(\mathrm{~m})$ & 201 \\
AWI & $T_{b}\left({ }^{\circ} \mathrm{C}\right)$ & -18.0 & 3.5 & $q_{b}\left(\mathrm{~g} \mathrm{~kg}^{-1}\right)$ & 270 \\
AWI & $T_{t}-T_{b}\left({ }^{\circ} \mathrm{C}\right)$ & 3.4 & 2.6 & $q_{t}-q_{b}\left(\mathrm{~g} \mathrm{~kg}^{-1}\right)$ & 0.14 \\
\hline
\end{tabular}

${ }^{*}$ Number of cases in the data sets: UNIS 39, UT 42, AWI 851.

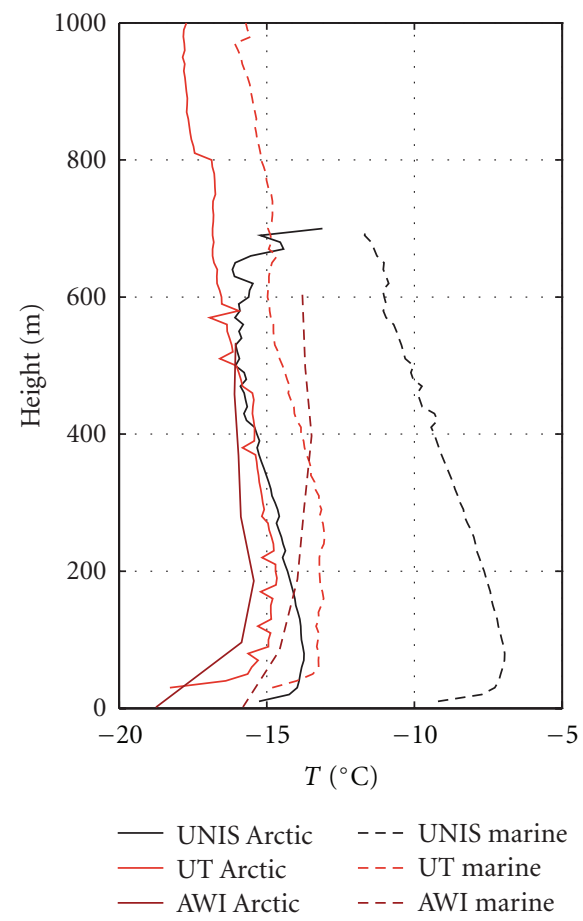

(a)

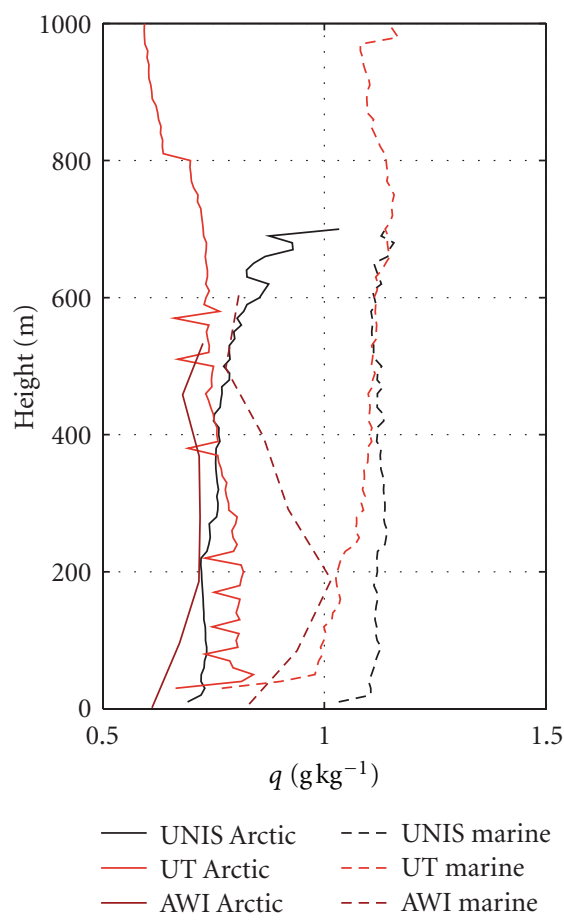

(b)

FIGURE 5: Mean profiles of the air temperature and specific humidity according to the UNIS, UT, and AWI soundings in cases of air masses of marine and Arctic origin.

sets (UT and AWI) indicated stronger temperature inversions in the Arctic than marine air masses. This is because the marine air masses entering in Kongsfjorden were colder than in Isfjorden; they either arrived from more northern areas or travelled a longer distance over Svalbard.

Considering the humidity profiles, UT, AWI, and UNIS data sets all indicated that the marine air masses were moister than the Arctic ones throughout the layer covered by the soundings (Figure 5(b)). The individual profiles often included elevated inversions, but their heights varied a lot, and therefore they do not clearly appear in the mean profiles. The mean profiles show humidity inversions right upwards from the lowest atmospheric observation height ( 2 or $9 \mathrm{~m}$ ) but, as mentioned above, the surface-specific humidity usually exceeded the near-surface value in the air.

4.3. Relationships between Variables. In this subsection, we only consider the properties of the strongest inversion of each vertical profile. First we report the strongest statistical relationships between the inversion properties, which do 


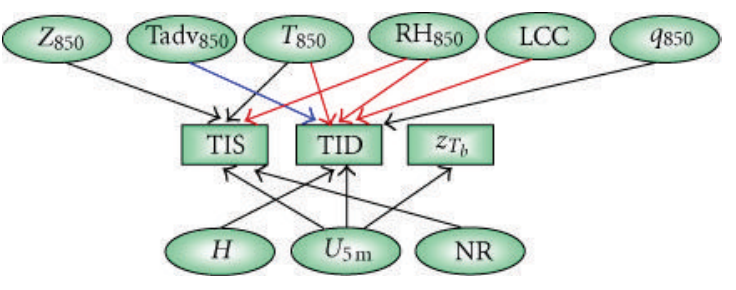

(a)

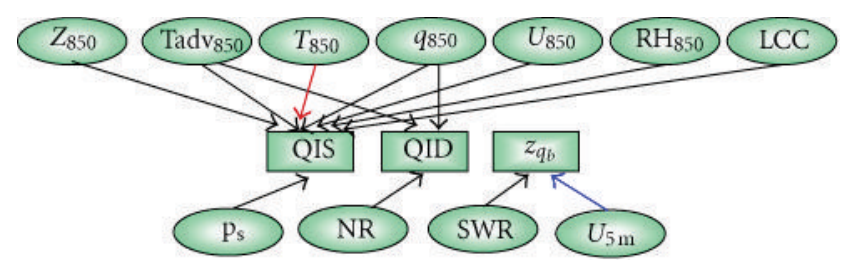

(b)

Figure 6: A schematic presentation of the observed relationships between inversion properties and other meteorological variables for (a) temperature and (b) humidity inversions. The thick red arrows denote statistically significant relationships detected from at least two tethersonde data sets, and the thick blue arrows mark the relationships with the highest correlation coefficients found in a single tethersonde data set (UT).

not necessarily have any causal links. In all three data sets, TIS increased with increasing TID (correlation coefficient $r$ ranged from 0.48 to 0.70 ), but QIS and QID had a significant positive correlation only in the AWI data set $(r=0.40)$. In the UT data, $z_{q b}$ was related to $z_{T b}(r=0.76)$, TIS $(r=-0.62)$, and QID $(r=0.52)$. The last finding is interesting: the higher the inversion base was, the thicker was the inversion, which demonstrates the dominating role of variations in the moisture content far above the surface, typically controlled by synoptic-scale processes.

Next we focus on potentially causal relationships, studying how the strength, depth, and base height of temperature and humidity inversions are affected by the large-scale flow variables at $850 \mathrm{hPa}$ level, above the mountain tops (wind speed $U_{850}$, air temperature $T_{850}$, specific humidity $q_{850}$, relative humidity $\mathrm{RH}_{850}$, temperature advection $T \mathrm{adv}_{850}$, and the height of the pressure level $Z_{850}$ ), as well as total cloud cover (TCC), low cloud cover (LCC), $5 \mathrm{~m}$ wind speed $\left(U_{5 \mathrm{~m}}\right)$, and the surface fluxes of sensible heat $(H)$, net radiation (NR), downward solar radiation (SWR), and downward longwave radiation (LWR). The fluxes are defined positive towards the surface. The statistically significant correlations are presented in Table 4, and a schematic summary of the relationships between variables in Figure 6.

4.3.1. Isfjorden. On average, TIS increased with increasing $Z_{850}$ and decreasing NR, $q_{850}$, and $\mathrm{RH}_{850}$ (Table 4). Temperature inversions were accordingly strong in high-pressure conditions with dry air. TID increased with increasing (downward) surface sensible heat flux and decreasing $q_{850}$. QIS was affected by the $850 \mathrm{hPa}$ variables and the surface pressure. A large QID was surprisingly related to a low $q_{850}$. This was because in cases with a large $q_{850}$ there was either no humidity inversion (marine air mass occupied the whole atmospheric column up to the $850 \mathrm{hPa}$ level) or only a very shallow internal boundary layer with a thin humidity inversion was generated at the sounding site. This was qualitatively in agreement with the UT results from Kongsfjorden, where warm-air advection decreased QID.

We observed a positive correlation between the near-surface wind speed and TIS $(r=0.51)$ and TID $(r=0.44)$. An explanation for this uncommon result is that the strongest and deepest inversions were associated with strong katabatic winds at the measurement site. Although the direct effect
TABLE 4: Potentially causal variables that have highest correlation coefficient $(r)$ with the properties of inversions and low-level jets. Only $|r| \geq 0.4$ with significance level exceeding 95\% are marked. See the text for definition of the symbols.

\begin{tabular}{|c|c|c|c|}
\hline \multirow{2}{*}{ Variable } & \multicolumn{3}{|c|}{ Statistical relationships } \\
\hline & AWI & UT & UNIS \\
\hline \multirow{4}{*}{ TIS } & $U_{5 \mathrm{~m}}:-0.40$ & & NR: -0.46 \\
\hline & $T_{850}: 0.55$ & No significant & $Z_{850}: 0.40$ \\
\hline & $\mathrm{RH}_{850}:-0.56$ & correlations & $q_{850}:-0.50$ \\
\hline & & & $\mathrm{RH}_{850}:-0.50$ \\
\hline \multirow{3}{*}{ TID } & $T_{850}: 0.43$ & $\operatorname{Tadv}_{850}: 0.76$ & H: 0.49 \\
\hline & $\mathrm{RH}_{850}:-0.45$ & $\mathrm{RH}_{850}:-0.56$ & $q_{850}:-0.43$ \\
\hline & & $T_{850}: 0.54$ & \\
\hline $\mathrm{z}_{T b}$ & Not analysed & $U_{5 \mathrm{~m}}: 0.58$ & $\begin{array}{c}\text { No } \\
\text { significant } \\
\text { correlations }\end{array}$ \\
\hline \multirow{4}{*}{ QIS } & $T_{850}: 0.64$ & $Z_{850}: 0.52$ & $P:-0.46$ \\
\hline & $q_{850}: 0.48$ & $U_{850}:-0.53$ & $T_{850}: 0.53$ \\
\hline & & LCC: 0.50 & $\operatorname{Tadv}_{850}: 0.43$ \\
\hline & & & $\mathrm{RH}_{850}:-0.56$ \\
\hline \multirow{2}{*}{ QID } & No significant & NR: -0.50 & $a_{0}=0 .-040$ \\
\hline & correlations & $\operatorname{Tadv}_{850}:-0.52$ & $48500^{\circ} 0.70$ \\
\hline $\mathrm{z}_{q b}$ & SWR: $r=0.53$ & $U_{5 \mathrm{~m}}: r=0.65$ & $\begin{array}{c}\text { No } \\
\text { significant } \\
\text { correlations }\end{array}$ \\
\hline
\end{tabular}

of a strong near-surface wind is to erode the inversions, the katabatic wind strengthened the inversions by advecting cold near-surface air to the measurement site.

4.3.2. Kongsfjorden. In the AWI data set, TIS and TID correlated with $T_{850}$ and $\mathrm{RH}_{850}$ (Table 4): strong and thick temperature inversions were favoured by warm, dry air at $850 \mathrm{hPa}$ level. A low $\mathrm{RH}_{850}$ kept LWR low, which strengthened inversions. A high $T_{850}$ had, however, two competing effects: to directly strengthen inversions and to increase LWR, which tends to weaken inversions. The former effect dominated. In the UT data, TID was strongly affected by $T a \mathrm{adv}_{850}$ $(r=0.76)$ and significantly also with $\mathrm{RH}_{850}$ and $T_{850}$. A multiple linear regression analysis [45] using $\mathrm{Tadv}_{850}$ and $\mathrm{RH}_{850}$ 
as variables explaining TID yielded a high $r$ of 0.88 with a root-mean-square error of only $30 \mathrm{~m}$. It is noteworthy that inclusion of surface variables did not improve the regression. See Section 6 for further discussion.

In the AWI results, QIS was largest when the air at $850 \mathrm{hPa}$ level was warm and moist (Table 4). In the UT data, a large QIS was favoured by a high $Z_{850}$ and LCC, as well as a low $U_{850}$. A large NR and warm-air advection decreased QID. The stronger the wind speed, the higher were $z_{T b}$ and $z_{q b}$.

4.4. Differences between Day and Night. We analysed the differences between day and night on the basis of the AWI data (Figure 2). Despite the high latitude (small diurnal amplitude in the solar zenith angle), the data showed clear diurnal cycles in downward and upward components of solar radiation, upward longwave radiation, surface temperature $\left(T_{S}\right), T_{2 \mathrm{~m}}, q_{2 \mathrm{~m}}$, and $\mathrm{RH}_{2 \mathrm{~m}}$ as well as in the strength and depth of temperature and humidity inversions (Figure 7; the quantitative numbers were naturally affected by the coarse vertical resolution). The diurnal cycles of TID and QID originated solely from the diurnal cycles in the inversion base heights. Our observations on daytime maximum of $z_{q b}$ are qualitatively in agreement with the daytime maximum of the base height of low clouds observed over the Antarctic sea ice [45].

The causal factors correlating (negatively) with the daytime TIS were $\mathrm{RH}_{850}$ and $U_{5 \mathrm{~m}}$. The daytime TID increased with increasing TIS. At night, warm air at the $850 \mathrm{hPa}$ level tended to generate strong and deep temperature inversions. These warm air masses were often close to saturation at the $850 \mathrm{hPa}$ level, suggesting that very small increase in the air humidity could have resulted in large changes in the inversion properties. Both during day and night, warm and moist air at the $850 \mathrm{hPa}$ level favoured strong humidity inversions. The $850 \mathrm{hPa}$ variables did not have any significant effect on daytime QID, but at night moist air at the $850 \mathrm{hPa}$ level with a large LWR and a warm and moist surface favoured thick inversions.

4.5. Strongest Inversions. The strongest humidity inversion over Kongsfjorden $(0.76 \mathrm{~g} / \mathrm{kg})$ was observed on 20 March at 12 UTC with warm air $\left(-15^{\circ} \mathrm{C}\right)$ advected from west at $850 \mathrm{hPa}$ level. During the preceding $24 \mathrm{~h}$, the cloud cover had been $6-8$ octas, but at noon it reduced to 3 octas, the snow surface cooled by $2.7^{\circ} \mathrm{C}$, and evaporation stopped.

The strongest temperature inversion over Kongsfjorden $\left(10.9^{\circ} \mathrm{C}\right)$ was observed on a clear night $(22-23 \mathrm{UTC})$ on 30 March when $T_{S}$ had decreased from -13 to $-26^{\circ} \mathrm{C}$ in $8 \mathrm{~h}$ but $T_{850}$ was still high $\left(-15^{\circ} \mathrm{C}\right)$, just starting to decrease. Over Isfjorden, the by far strongest temperature and humidity inversions $\left(6.5^{\circ} \mathrm{C}\right.$ and $0.28 \mathrm{~g} \mathrm{~kg}^{-1}$, resp.) were observed on 30 March 03-04 UTC, that is, during the same synoptic situation but $19 \mathrm{~h}$ earlier than in Kongsfjorden. The air was warm with the near-surface and $850 \mathrm{hPa}$ air temperatures 2.3 and $6.0^{\circ} \mathrm{C}$ higher, respectively, than the mean values during the campaign. Some $30-36 \mathrm{~h}$ earlier strong southerly winds had advected warm, moist, and cloudy air over Svalbard. The wind calmed down the day before, and in the night of 30
March wind turned to northwest, remaining weak $\left(4 \mathrm{~m} \mathrm{~s}^{-1}\right.$ both at the surface and $850 \mathrm{hPa}$ level), and the cloud fraction decreased from seven to three octas. The ECMWF analyses indicated subsidence of $0.03 \mathrm{~m} \mathrm{~s}^{-1}$ at the $850 \mathrm{hPa}$ level, which may have contributed to the breaking of the cloud cover. Accordingly, the warm, moist air at higher altitudes, the weak winds, and the break of the cloud cover generated optimal conditions for strong inversions.

The model experiments of Kilpeläinen et al. [44] showed that such inversions in a warm air mass were particularly challenging for the Weather Research and Forecast (WRF) model. During the warm period from 27 to 31 March, the simulated temperature profiles were basically slightly stable with a lapse rate of -5 to $-8^{\circ} \mathrm{C} \mathrm{km}^{-1}$ from the surface to the $850 \mathrm{hPa}$ level, only occasionally interrupted by weak, thin inversions. When the maximum temperature and humidity inversions were observed over Isfjorden, the modeled inversion strengths were only $0.3^{\circ} \mathrm{C}$ and $0.04 \mathrm{~g} \mathrm{~kg}^{-1}$. Altogether 163 temperature inversions were observed during the campaign, but only 80 were simulated, with TIS, TID, and QIS generally underestimated [44].

\section{Low-Level Jets}

5.1. Overview on the Wind Conditions. Due to the limitations of the tethersonde system described in Section 2.1, the observed wind speeds at both fjords were mostly weak or moderate. At Isfjorden, the main wind direction was southeasterly both near the surface and above the temperature inversion. The LLJs over Isfjorden were divided into two groups. Group 1 consists of 15 cases with the jet core wind direction between 130 and $240^{\circ}$ and the jet core below $100 \mathrm{~m}$. These jets were caused by a katabatic flow from Platåberget (Figure 1). Group 2 consists of three cases with the jet core wind directions between 280 and $340^{\circ}$. The origin of these LLJs is not clear. Hereafter we only analyse the Group 1 LLJs.

At Kongsfjorden, the surface wind directions were variable but wind above the near-surface temperature inversion was usually easterly or southeasterly. In all LLJs of the AWI data and in 13 of the 15 LLJs of the UT data, the core wind directions were southeasterly; we interpret the jets to be generated by katabatic flow from Kongsvegen Glacier (Figure 1, [41]). The LLJ statistics are summarized in Table 5. No diurnal cycle was detected from the LLJ properties $\left(z_{j}, U_{j}-\right.$ $U_{a}$ and $U_{j}$ ).

5.2. Variables Related to Low-Level Jet Properties. At Isfjorden, $z_{j}$ was large when the air was warm (Figure 8) from the surface to the inversion top, the atmospheric pressure was low, and the $850 \mathrm{hPa}$ flow was weak. At Kongsfjorden, the results were very different from Isfjorden (Figure 8 ): $z_{j}$ was larger and correlated negatively with the near-surface air temperature ( $r=-0.65$ in UT data). High LLJs over Kongsfjorden were also associated with warm-air advection; the larger the advection, the higher the jet core $(r=0.51$ in UT data).

We interpret the different results as follows. At Isfjorden, LLJs had their cores below $120 \mathrm{~m}$ altitude, and were related 


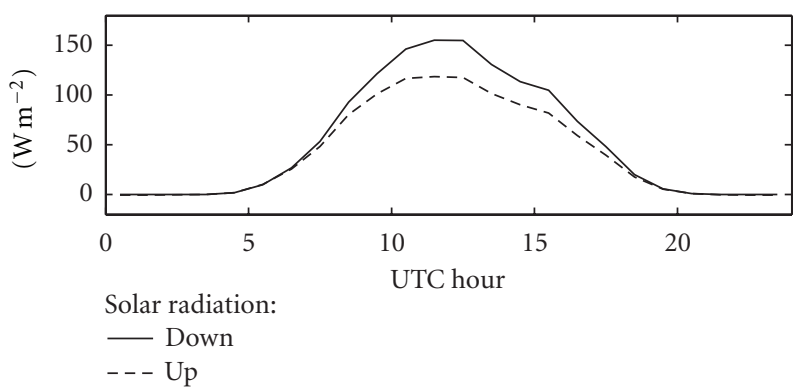

(a)

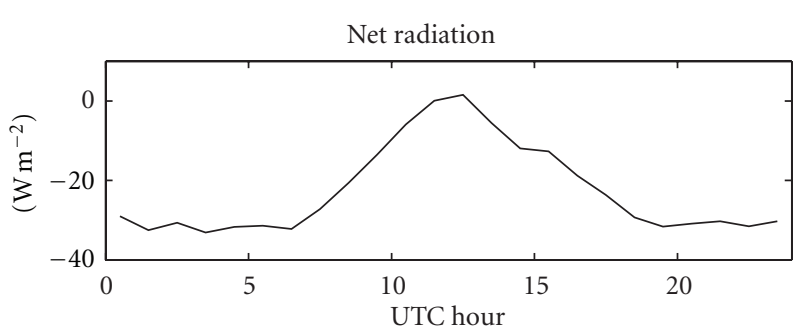

(c)

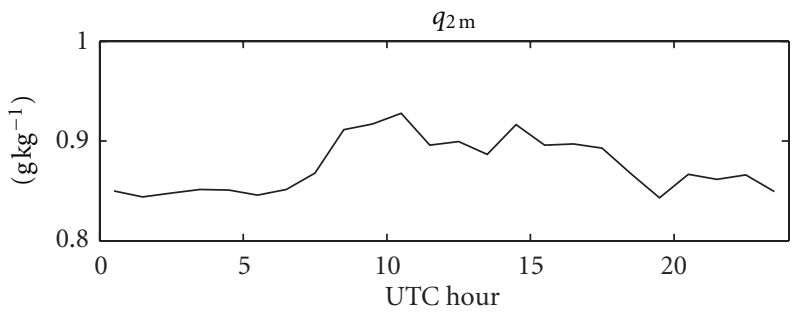

(e)

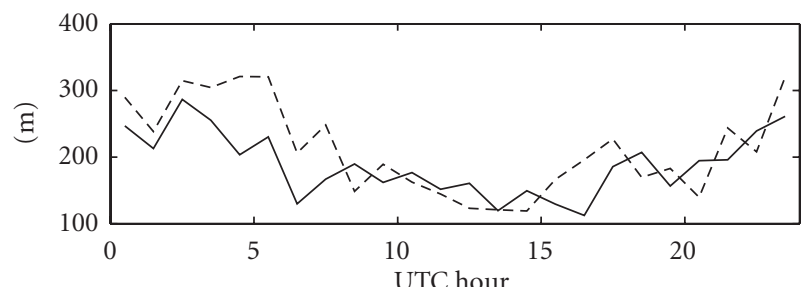

-- TID
-- QID

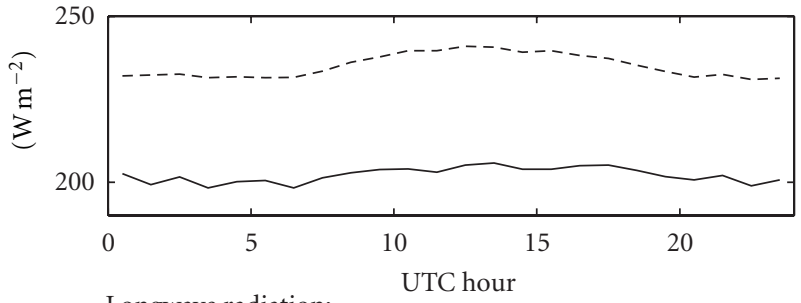

Longwave radiation:

- Down

- - - Up

(b)

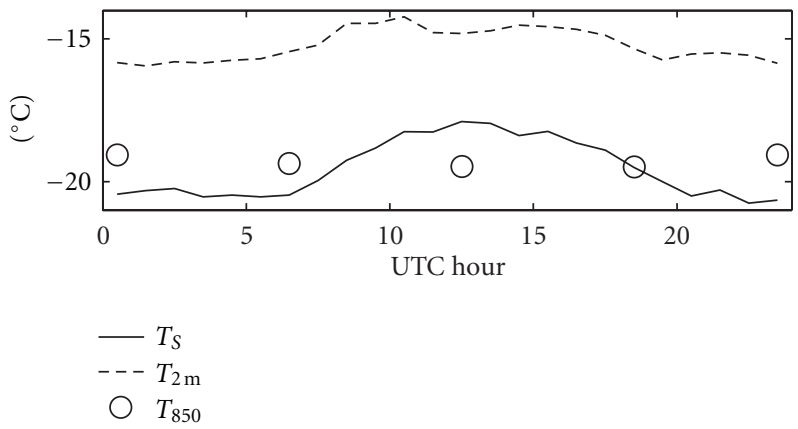

(d)

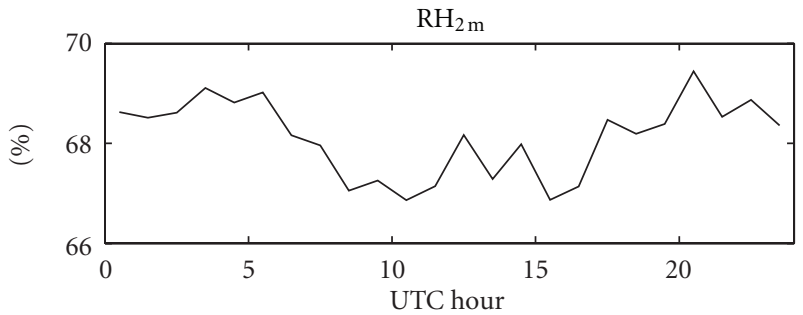

(f)

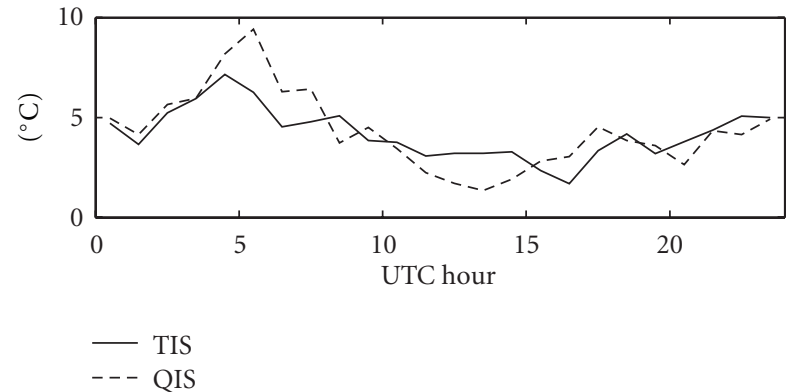

(h)

FIGURE 7: Average diurnal cycles of surface-layer observations and inversion properties, based on AWI soundings at Kongsfjorden.

to a katabatic flow from Platåberget. The near-surface air temperatures observed at the sounding site characterized the temperature of the katabatic flow at the coast. The fjord was ice-free with a constant surface temperature of about $-1.8^{\circ} \mathrm{C}$, and the air over the fjord was therefore heated via the turbulent fluxes from the sea. Hence, the colder the air flowing downslope, the closer to the surface it remained (Figure 8). At Kongsfjorden, however, the fjord in front of the observation site was frozen. Because of (a) adiabatic warming of the katabatic flow and (b) stronger stratification over the flat sea ice than on the slope (where the katabatic flow mixed the near-surface air), the katabatic flow was elevated above the cold-air pool on the sea ice and the flat sounding site. This interpretation is supported by observations and model results from Wahlenbergfjorden, Svalbard [35], Antarctic [46, 47], and midlatitude mountain valleys [48]. The above is also supported by the fact that in the Kongsfjorden UT data set the LLJ core was always above the temperature inversion top but at Isfjorden the LLJ core was more often located below the inversion top than above it. The role of warm-air 
TABLE 5: Statistics of low-level jet parameters.

\begin{tabular}{lcc}
\hline & Isfjorden (UNIS) & \\
Variable $(20$ cases $)$ & Mean & std \\
\hline$z_{j}(\mathrm{~m})$ & 65 & 65 \\
$z_{a}-z_{j}(\mathrm{~m})$ & 230 & 115 \\
$U_{j}\left(\mathrm{~m} \mathrm{~s}^{-1}\right)$ & 5.7 & 1.3 \\
$U_{j}-U_{a}\left(\mathrm{~m} \mathrm{~s}^{-1}\right)$ & 3.0 & 0.7 \\
\hline & Kongsfjorden (UT) & \\
Variable $(15$ cases $)$ & Mean & std \\
\hline$z_{j}(\mathrm{~m})$ & 514 & 361 \\
$z_{a}-z_{j}\left(\mathrm{~m}^{2}\right)$ & 224 & 102 \\
$U_{j}\left(\mathrm{~m} \mathrm{~s}^{-1}\right)$ & 6.5 & 1.1 \\
$U_{j}-U_{a}\left(\mathrm{~m} \mathrm{~s}^{-1}\right)$ & 3.6 & 1.0 \\
\hline & Kongsfjorden (AWI) \\
Variable $(355$ cases $)$ & Mean & \\
\hline$z_{j}(\mathrm{~m})$ & 206 & std \\
$z_{a}-z_{j}\left(\mathrm{~m}^{2}\right)$ & 268 & 103 \\
$U_{j}\left(\mathrm{~m} \mathrm{~s}^{-1}\right)$ & 5.6 & 106 \\
$U_{j}-U_{a}\left(\mathrm{~m} \mathrm{~s}^{-1}\right)$ & 3.6 & 1.8 \\
\hline
\end{tabular}

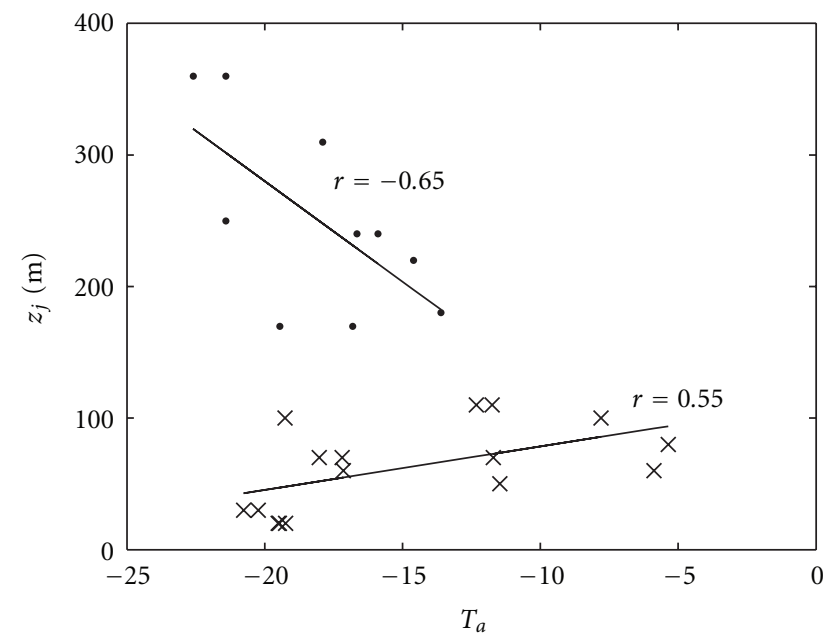

Figure 8: Dependence of the height of the LLJ core $\left(z_{j}\right)$ on nearsurface air temperature $\left(T_{a}\right)$ in Isfjorden (crosses) and Kongsfjorden (dots).

advection in lifting the LLJ core is in accordance with the above; when the warm air masses of the free atmosphere meet the mountain or glacier slopes, they mix with the katabatic flow, increasing its temperature, which favours the lift of the flow above the cold-air pool on the valley bottom (the advection at $850 \mathrm{hPa}$ level approximately represents the advection at the altitude of the upper parts of the Kongsvegen glacier $(800 \mathrm{~m}$ ) and the surrounding mountains (up to $1260 \mathrm{~m}$ )). Figure 9 schematically illustrates the mechanisms.

At Isfjorden, the LLJ core wind speed $U_{j}$ was stronger when temperature inversions were deep, surface net radiation was negative, and clouds were few. In the AWI Kong-

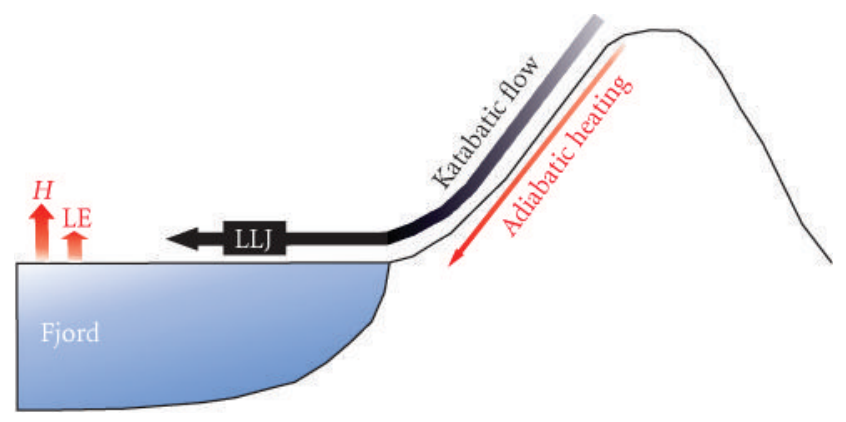

(a)

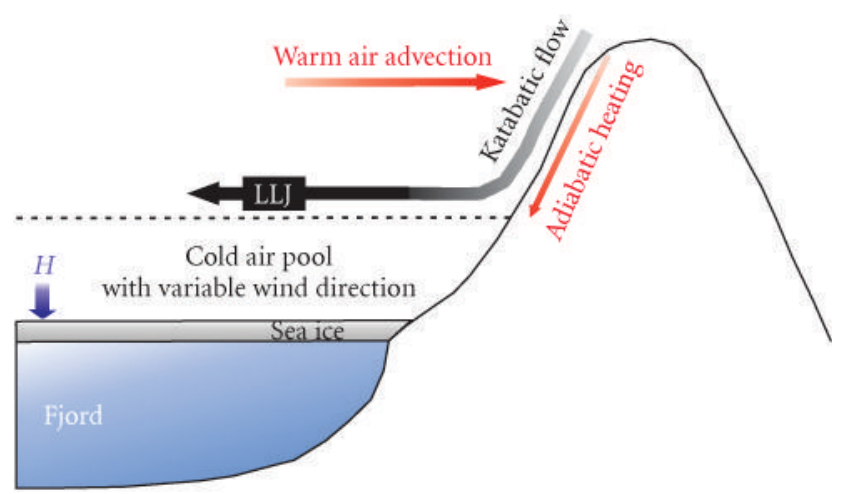

(b)

Figure 9: A schematic presentation of katabatic flows over (a) icefree Isfjorden and (b) ice-covered Kongsfjorden. $H$ and LE denote the turbulent fluxes of sensible and latent heat, respectively.

sfjorden data set, $U_{j}$ increased with increasing $T_{850}$ and decreasing LCC. Accordingly, factors related to stable stratification favoured a strong $U_{j}$ in both fjords. The core wind speed did not, however, correlate with the local stratification at the measurement sites (expressed in terms of the near-surface Richardson number or stability parameter $z / L$, where $L$ is the Obukhov length). This was because katabatic winds are generated due to stable stratification on sloping surfaces, but as the wind speed increases the local stratification is reduced due to wind-induced mixing [47], and the Obukhov length is not a relevant stability parameter over the slope, where turbulence is mostly governed by the $\operatorname{LLJ}[49,50]$.

Due to the problems in wind direction measurements, the tethersonde data did not allow studies on the role of directional shear in the generation of LLJs, but the AWI rawinsonde sounding data demonstrated the importance of this effect. In 5 of the 14 rawinsonde soundings made during the campaign, the jet occurred at the same height with a remarkable $\left(>90^{\circ}\right)$ change in the wind direction. In four of these five cases, the strongest winds were southeasterly $\left(90-130^{\circ}\right)$, indicating an air mass origin in the Kongswegen glacier (Figure 1). Accordingly, the directional shear was related to the katabatic winds lifted above the cold-air pool. Synoptic-scale baroclinicity, calculated on the basis of the thermal wind in the ECMWF analyses, did not contribute to the generation of the observed LLJs. 


\section{Discussion}

The simultaneous soundings with different practices yielded different results for temperature and specific humidity inversions as well as LLJs. Such a sensitivity analysis seems not to have been published previously, although captive balloons have been applied in meteorological research since the $1800 \mathrm{~s}$ [51] with systems comparable to ours since the 1970s [52]. The simultaneous AWI and UT soundings in Kongsfjorden revealed differences of the order of $100 \%$ in TID, QID, and QIS, with thicker inversions in the AWI data but stronger ones in the UT data, demonstrating the importance of a high vertical resolution. The rawinsonde sounding data, in turn, included large errors close to the surface. In addition to the measurement methodology, the actual values of the inversion parameters depend on the definitions, which vary in the literature. The results of Serreze et al. [1] for the Svalbard region, mostly based on radiosonde soundings in Barentsburg on the southern coast of Isfjorden (Figure 1), are comparable to our observations on TIS. Serreze et al. [1] showed, however, a mean TID of approximately $450 \mathrm{~m}$ for our study region in April-June, which is much higher than our data indicated. A potential explanation is that radiosonde soundings detect weak inversions at altitudes higher than those reached by a tethersonde, and these are identified as a part of the nearsurface inversion (if two inversion layers were separated by a layer less than $100 \mathrm{~m}$ thick, Serreze et al. [1] embedded this intermediate layer within the overall inversion layer).

The strength, depth, and base height of temperature and humidity inversions were related to each other. In general, strong inversions were deep and had their base at a high altitude. In both fjords, TIS, TID, QIS, and QID were affected by conditions both at the local surface and at the $850 \mathrm{hPa}$ pressure level, the latter being more important characterizing the effects of the large-scale flow over the Svalbard mountains. In general, dry air at $850 \mathrm{hPa}$ level favoured strong but thin temperature inversions, and warm air at $850 \mathrm{hPa}$ level favoured strong humidity inversions. Considering individual cases, the largest TIS and QIS both over Isfjorden and Kongsfjorden were observed in conditions of warmer-than-average air at the $850 \mathrm{hPa}$ level during the campaign. Kilpeläinen et al. [44] demonstrated that such inversions represent a challenge for numerical models, and our analyses suggested reasons for this: when the air mass is warm and the cloud cover breaks up, strong inversions are rapidly generated via surface cooling. Such changes in the cloud cover are very difficult to be reproduced by models [53].

Local radiative fluxes at the snow surface did not dominate the inversion properties (Table 4). In particular, the downward longwave radiation did not have a statistically significant role in any of the data sets. This is understandable because (a) the inversion strength and depth respond to the cumulative effect of surface forcing over the air mass trajectory, and the radiative fluxes measured at the fjord shore seldom represented the large-scale surface conditions under the trajectory well, and (b) via the effects of clouds, anomalies in the downward solar and longwave radiation compensated for each other. Hence, net radiation had more effect on the inversion properties (Table 4). Among the near-surface variables, wind speed was the most important in affecting inversion properties: TIS, $z_{T b}$, and $z_{q b}$ over Kongsfjorden. Mixing due to a strong near-surface wind effectively erodes the inversion layer, resulting in weaker and more elevated inversions. Note, however, that at the coast of Isfjorden, the strongest and deepest inversions were associated with strong near-surface katabatic flows, which strengthened the inversions by advecting cold air.

We found strong correlations between inversion properties and $850 \mathrm{hPa}$ variables. The strongest one resulted from a multiple regression with $\mathrm{Tadv}_{850}$ and $\mathrm{RH}_{850}$ as explaining variables for TID, yielding $r=0.88$. Besides basic understanding of the factors affecting inversions, such relationships may have some applicability. For example, many measurements on air chemistry and aerosols are regularly carried out in Svalbard, and information on the ABL structure is important for interpretation of the data [54]. Considering short-term forecasting, TID can be diagnosed from the output of operational numerical models, but the highest resolutions presently applied in operational NWP models for Svalbard are 4 and $8 \mathrm{~km}$, which make them very liable to errors in a fjord with a complex orography [42]. The model products for $850 \mathrm{hPa}$ variables are, however, more reliable [55]; via established empirical relationships with inversion properties they may provide a useful tool to forecast the inversion properties. However, this requires further studies.

\section{Conclusions}

We presented a unique set of tethersonde sounding data from two Svalbard fjords. We note, however, that due to restrictions to sounding activity caused by weather conditions and aviation safety rules, the results obtained do not well represent the full statistics of weather conditions during the campaign, just a selected subset. The most important findings of the study were as follows.

(i) A tethersonde sounding practice with a high vertical resolution was essential as it allowed detection of strong near-surface inversions and low-level jets, which were not well detected by rawinsonde soundings.

(ii) The properties of temperature and humidity inversions over Svalbard fjords in early spring were strongly affected by the synoptic-scale weather conditions above the mountains.

(iii) The strongest individual temperature and humidity inversions were observed in warm and moist (in the sense of specific humidity) air masses. In general, however, the strength and depth of the temperature inversions increased with decreasing relative humidity at the $850 \mathrm{hPa}$ level.

(iv) Although temperature inversions are often generated by radiative cooling of the surface, in our data the downward longwave radiation measured at the sounding site did not correlate with the inversion strength, depth, and base height. 
(v) Humidity inversions occurred as frequently as temperature inversions, but humidity inversions on average (a) had a larger base height and (b) were thicker than the temperature inversions. This was due to (a) the role of the snow surface as a sink for heat but usually not for moisture, and (b) the effect adiabatic cooling in reducing the temperature inversion depth.

(vi) Over the ice-covered Kongsfjorden, the jet core was located highest when the near-surface air was coldest: jets were lifted above the cold-air pool and associated inversion layer over the fjord. At the coast of the icefree Isfjorden, jet cores were located lower, often below the inversion top, and the core height was highest in cases of warmest air.

\section{Acknowledgments}

The fieldwork in Ny-Ålesund, Kongsfjorden, was supported by the European Centre for Arctic Environmental Research (ARCFAC) and the target financed project SF0180049s09 of the Ministry of Education and Research of the Republic of Estonia, and the data analyses by the 6th EU Framework Programme project DAMOCLES (Grant 18509). In particular, the authors thank Jürgen Graeser and Marcus Schumacher for their contribution in the field work, and Christof Lüpkes, Anne Sandvik, and three anonymous reviewers for their constructive comments on the paper.

\section{References}

[1] M. C. Serreze, J. D. Kahl, and R. C. Schnell, "Low-level temperature inversions of ehe Eurasian Arctic and comparisons with Soviet drifting station data," Journal of Climate, vol. 5, no. 6, pp. 615-629, 1992.

[2] J. D. Kahl, M. C. Serreze, and R. C. Schnell, "Tropospheric lowlevel temperature inversions in the Canadian Arctic," Atmosphere-Ocean, vol. 30, no. 4, pp. 511-529, 1992.

[3] M. Tjernström and R. G. Graversen, "The vertical structure of the lower Arctic troposphere analysed from observations and the ERA-40 reanalysis," Quarterly Journal of the Royal Meteorological Society, vol. 135, no. 639, pp. 431-443, 2009.

[4] R. A. Brost and J. C. Wyngaard, "A model study of the stably stratified planetary boundary layer," Journal of the Atmospheric Sciences, vol. 35, no. 8, pp. 1427-1440, 1978.

[5] J. C. Andre and L. Mahrt, "The nocturnal surface inversion and influence of clear-air radiative cooling," Journal of the Atmospheric Sciences, vol. 39, no. 4, pp. 864-878, 1982.

[6] S. W. Hoch, P. Calanca, R. Philipona, and A. Ohmura, "Yearround observation of longwave radiative flux divergence in Greenland," Journal of Applied Meteorology and Climatology, vol. 46, no. 9, pp. 1469-1479, 2007.

[7] J. E. Overland and P. S. Guest, "The Arctic snow and air temperature budget over sea ice during winter," Journal of Geophysical Research, vol. 96, no. 3, pp. 4651-4662, 1991.

[8] T. Vihma, J. Hartmann, and C. Lüpkes, "A case study of an onice air flow over the Arctic marginal sea-ice zone," BoundaryLayer Meteorology, vol. 107, no. 1, pp. 189-217, 2003.

[9] N. Busch, U. Ebel, H. Kraus, and E. Schaller, "The structure of the subpolar inversion-capped ABL," Meteorology and Atmospheric Physics, vol. 31, no. 1-2, pp. 1-18, 1982.
[10] J. A. Curry, W. B. Rossow, D. Randall, and J. L. Schramm, "Overview of Arctic cloud and radiation characteristics," Journal of Climate, vol. 9, no. 8, pp. 1731-1746, 1996.

[11] M. C. Serreze, R. G. Barry, and J. E. Walsh, "Atmospheric water vapor characteristics at $70^{\circ} \mathrm{N}$," Journal of Climate, vol. 8, no. 4, pp. 719-731, 1995.

[12] J. Sedlar and M. Tjernström, "Stratiform cloud-inversion characterization during the Arctic melt season," BoundaryLayer Meteorology, vol. 132, no. 3, pp. 455-474, 2009.

[13] J. Curry, "On the formation of continental polar air," Journal of the Atmospheric Sciences, vol. 40, no. 9, pp. 2278-2292, 1983.

[14] E. Jakobson and T. Vihma, "Atmospheric moisture budget over the Arctic on the basis of the ERA-40 reanalysis," International Journal of Climatology, vol. 30, no. 14, pp. 2175-2194, 2010.

[15] R. B. Stull, An Introduction to Boundary Layer Meteorology, Kluwer Academic Publishers, Dordrecht, The Netherlands, 1988.

[16] A. J. Thorpe and T. H. Guymer, "The nocturnal jet," Quarterly Journal of the Royal Meteorological Society, vol. 103, no. 438, pp. 633-653, 1977.

[17] E. L. Andreas, K. J. Claffey, and A. P. Makshtas, "Low-level atmospheric jets and inversions over the Western Weddell Sea," Boundary-Layer Meteorology, vol. 97, no. 3, pp. 459-486, 2000.

[18] A. S. Smedman, M. Tjernström, and U. Högström, "Analysis of the turbulence structure of a marine low-level jet," BoundaryLayer Meteorology, vol. 66, no. 1-2, pp. 105-126, 1993.

[19] T. Vihma, J. Uotila, and J. Launiainen, "Air-sea interaction over a thermal marine front in the Denmark Strait," Journal of Geophysical Research, vol. 103, no. C12, pp. 27665-27678, 1998.

[20] R. M. Banta, "Stable-boundary-layer regimes from the perspective of the low-level jet," Acta Geophysica, vol. 56, no. 1, pp. 58-87, 2008.

[21] R. H. Langland, P. M. Tag, and R. W. Fett, "An ice breeze mechanism for boundary-layer jets," Boundary-Layer Meteorology, vol. 48, no. 1-2, pp. 177-195, 1989.

[22] I. A. Renfrew and P. S. Anderson, "Profiles of katabatic flow in summer and winter over Coats Land, Antarctica," Quarterly Journal of the Royal Meteorological Society, vol. 132, no. 616, pp. 779-802, 2006.

[23] J. C. King and J. Turner, Antarctic Meteorology and Climatology, Cambridge University Press, Cambridge, UK, 1997.

[24] S. S. Zilitinkevich and I. N. Esau, "Resistance and heat/mass transfer laws for neutral and stable planetary boundary layers: old theory advanced and re-evaluated," Quarterly Journal of the Royal Meteorological Society, vol. 131, pp. 1863-1892, 2005.

[25] L. Mahrt, "Stratified atmospheric boundary layers," BoundaryLayer Meteorology, vol. 90, no. 3, pp. 375-396, 1999.

[26] C. Lüpkes, T. Vihma, G. Birnbaum, and U. Wacker, "Influence of leads in sea ice on the temperature of the atmospheric boundary layer during polar night," Geophysical Research Letters, vol. 35, no. L03805, 5 pages, 2008.

[27] C. Lüpkes, V. M. Gryanik, B. Witha, M. Gryschka, S. Raasch, and T. Gollnik, "Modeling convection over Arctic leads with LES and a non-eddy-resolving microscale model," Journal of Geophysical Research, vol. 113, Article ID C09028, 17 pages, 2008.

[28] G. S. Poulos and S. P. Burns, "An evaluation of bulk Ri-based surface layer flux formulas for stable and very stable conditions with intermittent turbulence," Journal of the Atmospheric Sciences, vol. 60, no. 20, pp. 2523-2537, 2003. 
[29] M. Tjernström, M. Zagar, G. Svensson et al., "Modelling the Arctic boundary layer: an evaluation of six ARCMIP regionalscale models using data from the SHEBA project," BoundaryLayer Meteorology, vol. 117, no. 2, pp. 337-381, 2005.

[30] E. M. Tastula and T. Vihma, "WRF model experiments on the Antarctic atmosphere in winter," Monthly Weather Review, vol. 139, no. 4, pp. 1279-1291, 2011.

[31] E. Atlaskin and T. Vihma, "Validation of numerical weather prediction results for wintertime nocturnal boundary-layer temperatures," submitted to Quarterly Journal of the Royal Meteorological Society.

[32] R. G. Barry, Mountain Weather and Climate, Cambridge University Press, Cambridge, UK, 2008.

[33] E. J. Førland, I. Hanssen-Bauer, and P. O. Nordli, “Climate statistics and longterm series of temperature and precipitation at Svalbard and Jan Mayen," DNMI Report, Klima 21/97, p. 72, 1997.

[34] T. Kilpeläinen and A. Sjöblom, "Momentum and sensible heat exchange in an ice-free Arctic fjord," Boundary-Layer Meteorology, vol. 134, pp. 109-130, 2010.

[35] E. Mäkiranta, T. Vihma, A. Sjöblom, and E. M. Tastula, “Observations and modelling of the atmospheric boundary layer over sea ice in a Svalbard fjord," Boundary-Layer Meteorolpgy, vol. 140, no. 1, pp. 105-123, 2011.

[36] H. J. Beine, S. Argentini, A. Maurizi, G. Mastrantonio, and A. Viola, "The local wind field at Ny-Ålesund and the Zeppelin mountain at Svalbard," Meteorology and Atmospheric Physics, vol. 78, pp. 107-113, 2001.

[37] S. Argentini, A. P. Viola, G. Mastrantonio, A. Maurizi, T. Georgiadis, and M. Nardino, "Characteristics of the boundary layer at $\mathrm{Ny}$-Ålesund in the Arctic during the ARTIST field experiment," Annals of Geophysics, vol. 46, no. 2, pp. 185-196, 2003.

[38] A. D. Sandvik and B. R. Furevik, "Case study of a coastal jet at Spitsbergen-Comparison of SAR- and model-estimated wind," Monthly Weather Review, vol. 130, no. 4, pp. 10401051, 2002.

[39] T. Vihma, C. Lüpkes, J. Hartmann, and H. Savijärvi, "Observations and modelling of cold-air advection over Arctic sea ice," Boundary-Layer Meteorology, vol. 117, no. 2, pp. 275-399, 2005.

[40] J. Reuder, P. Brisset, M. Jonassen, M. Müller, and S. Mayer, "The small unmanned meteorological observer SUMO: a new tool for atmospheric boundary layer research," Meteorologische Zeitschrift, vol. 18, no. 2, pp. 141-147, 2009.

[41] J. Livik, An Observational and Numerical Study of Local Winds in Kongsfjorden, Spitsbergen, M.S. thesis, Geophysical Institute, University of Bergen, Bergen, Norway, 2011.

[42] T. Kilpeläinen, T. Vihma, and H. Ólafsson, "Modelling of spatial variability and topographic effects over Arctic fjords in Svalbard," Tellus A, vol. 63, no. 2, pp. 223-237, 2011.

[43] U. Schauer, "The release of brine-enriched shelf water from Storfjord into the Norwegian Sea," Journal of Geophysical Research, vol. 100, no. C8, pp. 16015-16028, 1995.

[44] T. Kilpeläinen, T. Vihma, M. Manninen et al., "Modelling the vertical structure of the atmospheric boundary layer over Arctic fjords in Svalbard," submitted to Quarterly Journal of the Royal Meteorological Society.

[45] T. Vihma, M. M. Johansson, and J. Launiainen, "Radiative and turbulent surface heat fluxes over sea ice in the western Weddell Sea in early summer," Journal of Geophysical Research, vol. 114, no. C04019, 18 pages, 2009.
[46] I. A. Renfrew, "The dynamics of idealized katabatic flow over a moderate slope and ice shelf," Quarterly Journal of the Royal Meteorological Society, vol. 130, no. 598, pp. 1023-1045, 2004.

[47] T. Vihma, E. Tuovinen, and H. Savijärvi, "Interaction katabatic winds and near-surface temperatures in the Antarctic," Journal of Geophysical Research, vol. 116, no. D21119, 14 pages, 2011.

[48] C. B. Clements, C. D. Whiteman, and J. D. Horel, "Cold-airpool structure and evolution in a mountain basin: Peter Sinks, Utah," Journal of Applied Meteorology, vol. 42, no. 6, pp. 752768, 2003.

[49] B. Grisogono, L. Kraljevic, and A. Jericevic, "The low-level katabatic jet height versus Monin-Obukhov height," Quarterly Journal of the Royal Meteorological Society, vol. 133, no. 629, pp. 2133-2136, 2007.

[50] R. M. Banta, Y. L. Pichugina, and W. A. Brewer, "Turbulent velocity-variance profiles in the stable boundary layer generated by a nocturnal low-level jet," Journal of the Atmospheric Sciences, vol. 63, no. 11, pp. 2700-2719, 2006.

[51] J. L. DuBois, R. P. Multhauf, and C. A. Ziegler, The Invention and Development of the Radiosonde, with a Catalog of UpperAtmospheric Telemetering Probes in the National Museum of American History, Smithsonian Studies in History and Technology, no. 53, Smithsonian Institution Press, Washington, DC, USA, 2002.

[52] A. L. Morris, D. B. Call, and R. B. McBeth, "A small tethered balloon sounding system," Bulletin of the American Meteorological Society, vol. 56, no. 9, pp. 964-969, 1975.

[53] M. Tjernström, J. Sedlar, and M. D. Shupe, "How well do regional climate models reproduce radiation and clouds in the Arctic? An evaluation of ARCMIP simulations," Journal of Applied Meteorology and Climatology, vol. 47, no. 9, pp. 24052422, 2008.

[54] M. Tuckermann, R. Ackermann, C. Gölz et al., "DOAS-observation of halogen radical-catalysed arctic boundary layer ozone destruction during the ARCTOC-campaigns 1995 and 1996 in Ny-Ålesund, Spitsbergen," Tellus B, vol. 49, no. 5, pp. 533-555, 1997.

[55] C. Lüpkes, T. Vihma, E. Jakobson, G. K. Langlo, and A. Tetzlaff, "Meteorological observations from ship cruises during summer to the central Arctic: a comparison with reanalysis data," Geophysical Research Letters, vol. 37, no. L09810, 4 pages, 2010. 

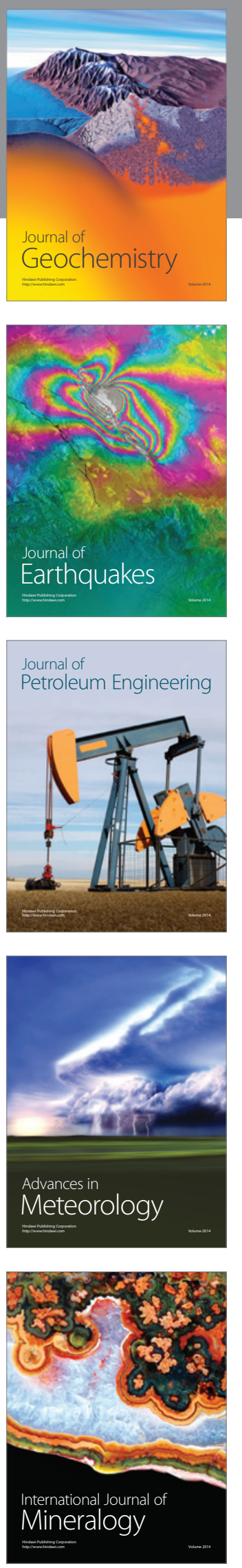
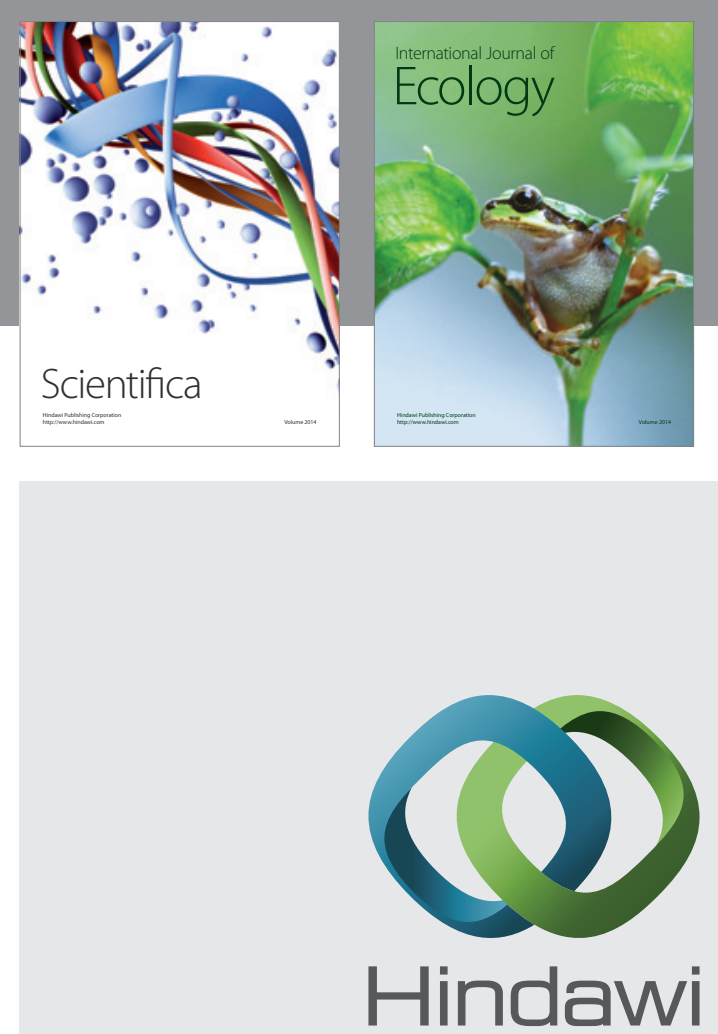

Submit your manuscripts at http://www.hindawi.com
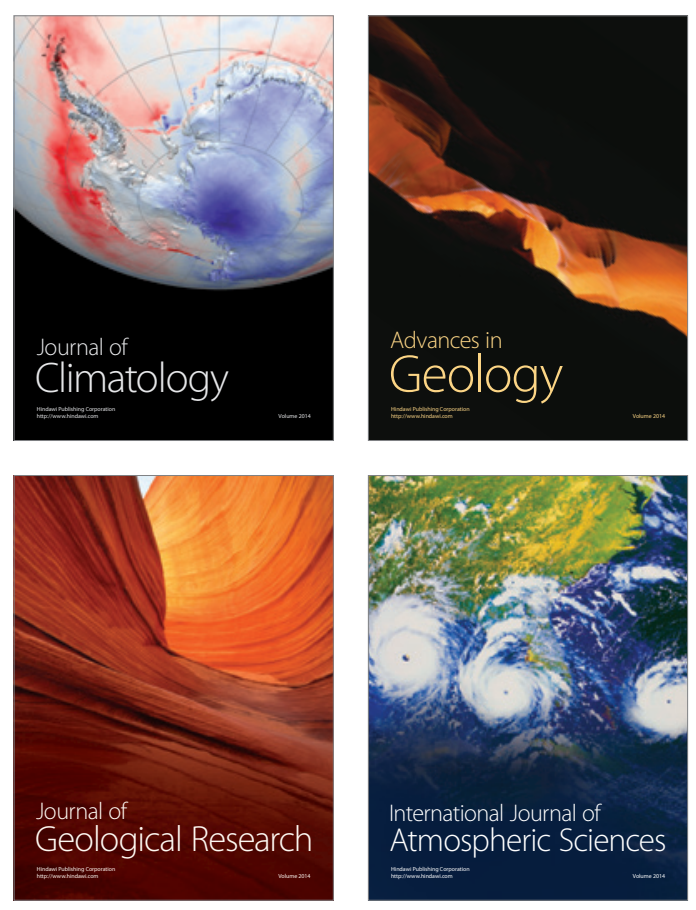
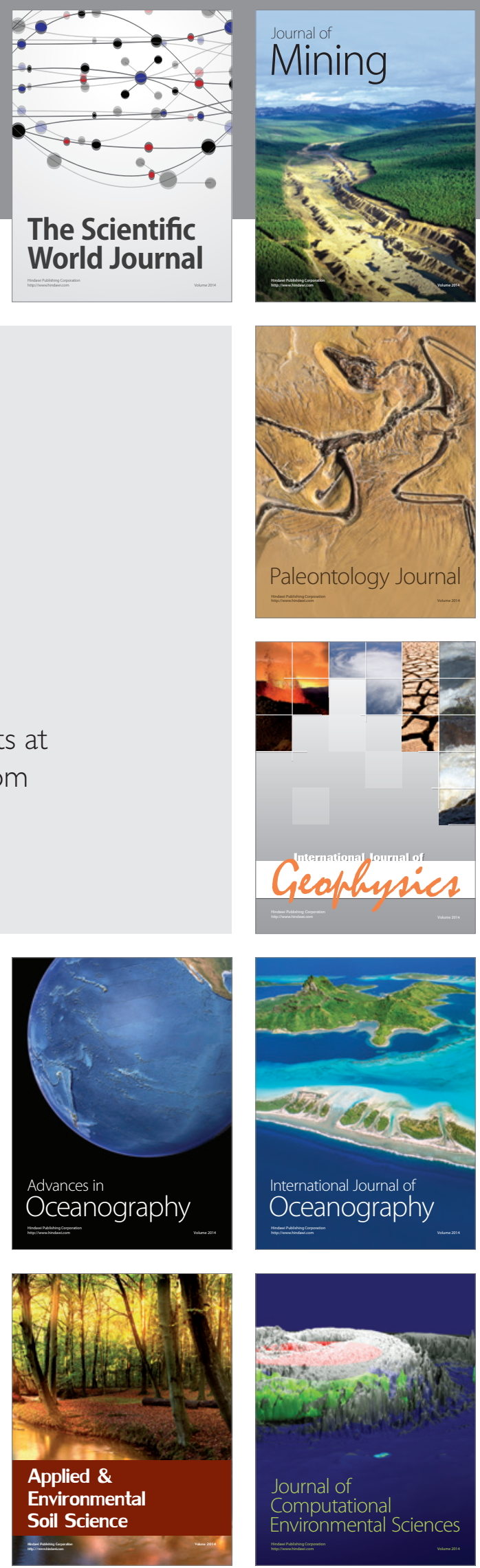